\title{
Tectono-thermal evolution of Oman's Mesozoic passive continental margin under the obducting Semail Ophiolite: a case study of Jebel Akhdar, Oman
}

\author{
Arne Grobe ${ }^{1,2}$, Christoph von Hagke ${ }^{1,6}$, Ralf Littke ${ }^{2}$, István Dunkl ${ }^{3}$, Franziska Wübbeler ${ }^{1}$, Philippe Muchez ${ }^{4}$, and \\ Janos L. Urai ${ }^{1,5}$ \\ ${ }^{1}$ Structural Geology, Tectonics, and Geomechanics, EMR Group, RWTH Aachen University, Aachen, Germany \\ ${ }^{2}$ Geology and Geochemistry of Petroleum and Coal, EMR Group, RWTH Aachen University, Aachen, Germany \\ ${ }^{3}$ Sedimentology \& Environmental Geology, Geoscience Center, Georg-August-Universität Göttingen, Göttingen, Germany \\ ${ }^{4}$ KU Leuven, Geodynamics and Geofluids Research Group, Department of Earth and Environmental Sciences, \\ Leuven, Belgium \\ ${ }^{5}$ Department of Applied Geoscience, German University of Technology in Oman GUtech, Muscat, Oman \\ ${ }^{6}$ Institute of Geology \& Palaeontology, EMR Group, RWTH Aachen University, Aachen, Germany
}

Correspondence: Arne Grobe (arne.grobe@ rwth-aachen.de)

Received: 31 July 2018 - Discussion started: 14 August 2018

Revised: 19 December 2018 - Accepted: 31 December 2018 - Published: 18 January 2019

\begin{abstract}
We present a study of pressure and temperature evolution in the passive continental margin under the Oman Ophiolite using numerical basin models calibrated with thermal maturity data, fluid-inclusion thermometry, and lowtemperature thermochronometry and building on the results of recent work on the tectonic evolution. Because the Oman mountains experienced only weak post-obduction overprint, they offer a unique natural laboratory for this study.

Thermal maturity data from the Adam Foothills constrain burial in the basin in front of the advancing nappes to at least $4 \mathrm{~km}$. Peak temperature evolution in the carbonate platform under the ophiolite depends on the burial depth and only weakly on the temperature of the overriding nappes, which have cooled during transport from the oceanic subduction zone to emplacement. Fluid-inclusion thermometry yields pressure-corrected homogenization temperatures of 225 to $266^{\circ} \mathrm{C}$ for veins formed during progressive burial, 296$364^{\circ} \mathrm{C}$ for veins related to peak burial, and 184 to $213{ }^{\circ} \mathrm{C}$ for veins associated with late-stage strike-slip faulting. In contrast, the overlying Hawasina nappes have not been heated above $130-170^{\circ} \mathrm{C}$, as witnessed by only partial resetting of the zircon $(\mathrm{U}-\mathrm{Th}) / \mathrm{He}$ thermochronometer.

In combination with independently determined temperatures from solid bitumen reflectance, we infer that the fluid inclusions of peak-burial-related veins formed at minimum
\end{abstract}

pressures of 225-285 MPa. This implies that the rocks of the future Jebel Akhdar Dome were buried under $8-10 \mathrm{~km}$ of ophiolite on top of $2 \mathrm{~km}$ of sedimentary nappes, in agreement with thermal maturity data from solid bitumen reflectance and Raman spectroscopy.

Rapid burial of the passive margin under the ophiolite results in sub-lithostatic pore pressures, as indicated by veins formed in dilatant fractures in the carbonates. We infer that overpressure is induced by rapid burial under the ophiolite. Tilting of the carbonate platform in combination with overpressure in the passive margin caused fluid migration towards the south in front of the advancing nappes.

Exhumation of the Jebel Akhdar, as indicated by our zircon $(\mathrm{U}-\mathrm{Th}) / \mathrm{He}$ data and in agreement with existing work on the tectonic evolution, started as early as the Late Cretaceous to early Cenozoic, linked with extension above a major listric shear zone with top-to-NNE shear sense. In a second exhumation phase the carbonate platform and obducted nappes of the Jebel Akhdar Dome cooled together below ca. $170^{\circ} \mathrm{C}$ between 50 and $40 \mathrm{Ma}$ before the final stage of anticline formation. 


\section{Introduction}

The Permian-Mesozoic platform sediments of north Oman (Fig. 1; e.g., Beurrier et al., 1986; Glennie et al., 1974; Lippard et al., 1982) with hydrocarbon accumulations in the southern foreland of the Jebel Akhdar Dome (Figs. 1 and 2) are overlain by the Semail Ophiolite nappe complex, the largest and best-preserved ophiolite on Earth. Limited tectonic extension after obduction, followed by uplift, folding, and deep erosion, and the present-day arid climate formed exceptional exposures in three tectonic windows and in the foreland fold-and-thrust belt of the Oman mountains (Fig. 1). The structural and tectonic evolution of the Oman mountains has been one main focus of our group in the last 15 years (e.g., Arndt et al., 2014; Gomez-Rivas et al., 2014; Grobe et al., 2016, 2018; Hilgers et al., 2006; Holland et al., 2009b; Virgo et al., 2013a, b) and was investigated in many other studies focusing on tectonic history (Breton et al., 2004; Cooper et al., 2014; Glennie et al., 1973, 1974; Grobe et al., 2018; Loosveld et al., 1996; Searle, 2007), stratigraphic sequences (Van Buchem et al., 2002; Grelaud et al., 2006; Homewood et al., 2008), geodynamic modeling (Duretz et al., 2015), hydrocarbon source rocks (Van Buchem et al., 1996; Philip et al., 1995; Scott, 1990), and reservoir rocks (Arndt et al., 2014; De Keijzer et al., 2007; Koehrer et al., 2011; Virgo et al., 2013b). Less well known is the temperature and pressure evolution of the sub-ophiolite passive margin units and the subsequent cooling history of the Jebel Akhdar (Aldega et al., 2017; Grobe et al., 2018; Hansman et al., 2017; Poupeau et al., 1998; Saddiqi et al., 2006). This information is vital for our understanding of the timetemperature history of overthrusted margins and would allow us to further constrain obduction dynamics and forebulge migration. Combining peak temperature evolution with cooling ages links the burial history with phases of orogeny.

In other orogens, peak temperatures related to nappe emplacement were reconstructed by analyzing the thermal maturity of finely dispersed organic material (e.g., Teichmüller and Teichmüller, 1986; Zagros: Mashhadi et al., 2015; Holy Cross Mountain: Schito et al., 2017; eastern Alps: Lünsdorf et al., 2012; southern Alps: Rantitsch and Rainer, 2003; Apennines: Reutter et al., 1988). However, the number of studies of thermal and pressure effects on overthrust sedimentary basins is limited and modeling approaches to reconstruct such large-scale overthrusts are increasing but still few (e.g., Aldega et al., 2018; Deville and Sassi, 2006; Ferreiro Mählmann, 2001; Jirman et al., 2018; Oxburgh and Turcotte, 1974; Roure et al., 2010; Schito et al., 2018; Wygrala, 1989). In these studies, a main difficulty is to differentiate between the temperature history of overthrusting and overprinting by later phases of orogeny. In the Oman mountains, peak temperatures reached by obduction have not been overprinted. The whole Permian-Mesozoic sequence of the carbonate platform below the ophiolite is well exposed, provid- ing outcrop to study the pressure and temperature history of this rapidly buried passive margin sequence.

In this paper we present new thermal maturity, thermochronology, and fluid-inclusion data and integrate them into a numerical basin model of the pressure-temperature evolution along a transect extending from the undeformed passive margin sequence in the south to the Batinah coast in the north (Fig. 2). This helps to constrain temperature and pressure conditions of maximum burial and the time of dome formation and exhumation linked to the structural and tectonic evolution of the area (Grobe et al., 2018). Our results for the Oman mountains can be used to understand more deformed orogens and shed light on fluid migration in the early stages of orogeny and exhumation related to orogenic collapse.

\section{Geological setting}

\subsection{Tectonic setting}

Along the northeastern coast of Arabia, the NW-SE-oriented Oman mountains form a more than $400 \mathrm{~km}$ long anticlinal orogen (Fig. 1). The mountain belt consists of allochthonous sedimentary and ophiolitic nappes thrust onto a PermianMesozoic passive continental margin (Breton et al., 2004; Glennie et al., 1973; Loosveld et al., 1996; Searle and Cox, 2002).

This continental margin was formed during opening of the Neotethyan Ocean (Loosveld et al., 1996) and the formation of the Permian-Mesozoic Hawasina basin (Béchennec et al., 1988; Bernoulli et al., 1990). The initiation of subsea thrusting of the future Semail Ophiolite onto the Arabian plate at 97-92 Ma is recorded by U-Pb geochronology (Rioux et al., 2013, 2016; Warren et al., 2005) and ${ }^{40} \mathrm{Ar} /{ }^{39} \mathrm{Ar}$ dating of the metamorphic sole (Hacker et al., 1996). The advancing ophiolite caused a flexural forebulge that moved southwestwards through the passive margin during the Upper Cretaceous (Robertson, 1987). Forebulge migration induced up to $1100 \mathrm{~m}$ of uplift of the Permian-Mesozoic Arabian platform and erosion of the Cretaceous platform sediments (Searle, 2007), causing the Wasia-Aruma break (Robertson, 1987).

During this convergence, parts of the Hawasina ocean sediments and volcanic units became detached and accreted in front of and beneath the ophiolite nappe (Béchennec et al., 1988, 1990; Glennie et al., 1974; Searle et al., 2003; Warburton et al., 1990). Palinspastic reconstructions of the Hawasina nappes locate the position of the initial ophiolite thrusting 300-400 km offshore of the Arabian coast (Béchennec et al., 1988; Glennie et al., 1974).

In the carbonate platform, burial under the advancing nappes led to the generation of overpressure cells and the formation of three crack-seal calcite vein generations (GomezRivas et al., 2014; Grobe et al., 2018; Hilgers et al., 2006; Holland et al., 2009b; Virgo, 2015). The highest grades of 


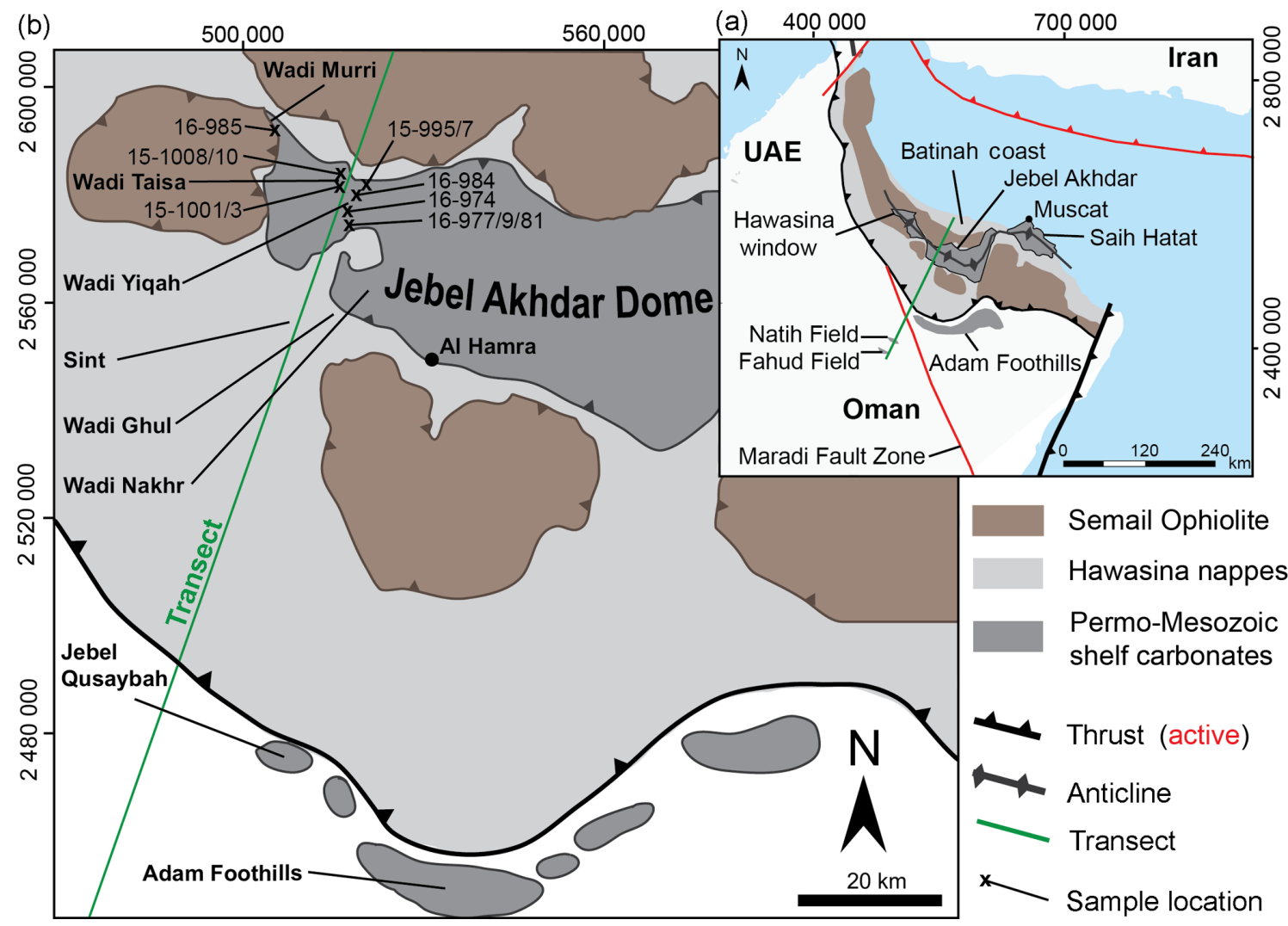

Figure 1. (a) Tectonic setting of the Oman mountains. In dark gray are the three tectonic windows of Hawasina, Jebel Akhdar, and Saih Hatat, as well as the Adam Foothills. Brown areas show the exposed Semail Ophiolite, black lines denote the obduction fronts of Semail and Masirah ophiolites, and red lines denote lithosphere-scale active faults. The modeled transect (black line) crosscuts the Jebel Akhdar window and continues to the Natih and Fahud oil fields in the southwestern mountain foreland. (b) Geologic map of the Jebel Akhdar window with the location of the modeled transect (solid black line) and the locations of thermal maturity data (x).

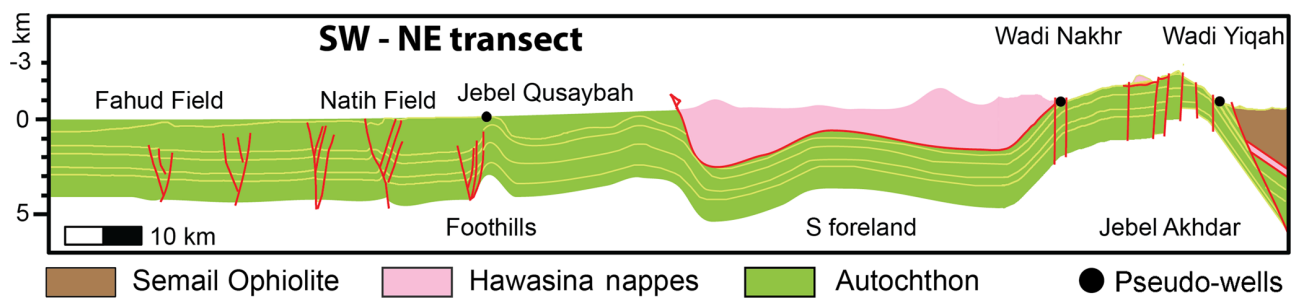

Figure 2. Structural transect used for modeling the Jebel Akhdar Dome and its southern foreland (Al-Lazki et al., 2002; Filbrandt et al., 2006; Searle, 2007; Warburton et al., 1990). Highlighted are the locations of the pseudo-wells (black circles) in Wadi Nakhr, Wadi Yiqah, and at Jebel Qusaybah, Adam Foothills, which were used for model calibration.

metamorphism are recorded by eclogites exposed in As Sifah (Fig. 1a) at ca. $79 \mathrm{Ma}$ (Warren et al., 2003).

The sedimentary record on the Batinah coast and the foreland, as well as laterite formation on top of the ophiolite, suggests subaerial exposure and a slowdown or stopped obduction before lower marine conditions were restored in the Maastrichtian (Coleman, 1981; Forbes et al., 2010; Nolan et al., 1990). This slowdown might relate to the formation of the Makran subduction zone (Agard et al., 2005; Grobe et al., 2018; Hassanzadeh and Wernicke, 2016; Jacobs et al.,
2015; Mouthereau, 2011) preserving the early stage of the obduction orogen in Oman.

In the Jebel Akhdar, post-obduction extension took place along ductile top-to-NNE shear zones at $64 \pm 4 \mathrm{Ma}$ (Grobe et al., 2018; Hansman et al., 2018), followed by NW-SEstriking normal fault systems (Al-Wardi and Butler, 2007; Fournier et al., 2006; Grobe et al., 2018; Hanna, 1990; Hilgers et al., 2006; Holland et al., 2009a, b; Loosveld et al., 1996; Mattern and Scharf, 2018; Virgo, 2015). 

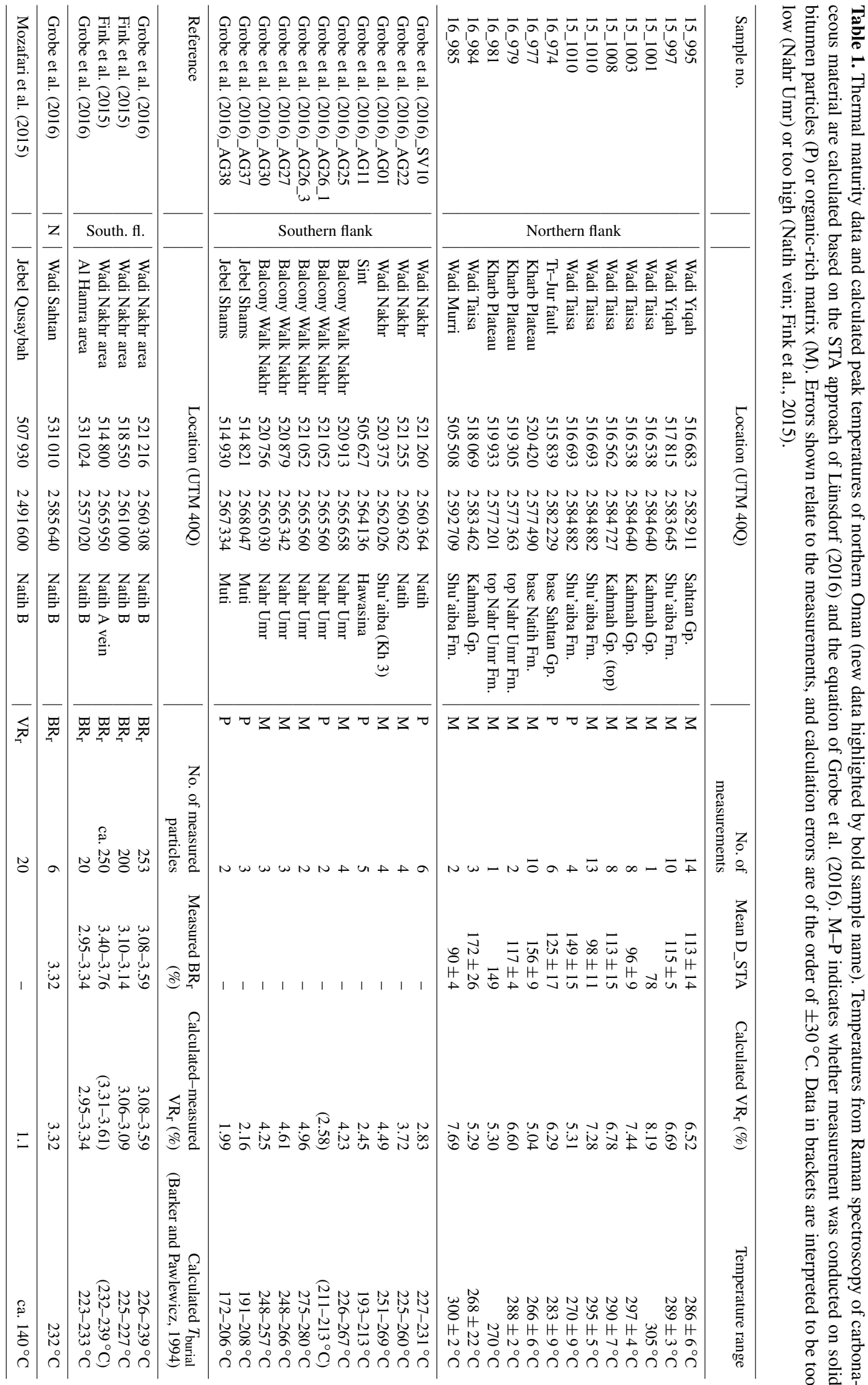
Renewed Arabia-Eurasia convergence during the Cenozoic formed the three dome structures. The timing of the formation and exhumation of the Jebel Akhdar Dome is still debated. Stratigraphic arguments for a Late Cretaceous doming are Maastrichtian rocks unconformably deposited on Hawasina (Bernoulli et al., 1990; Fournier et al., 2006; Hanna, 1990; Nolan et al., 1990), while inclined Miocene strata at the northern fringes of the dome point to a Miocene doming (Glennie et al., 1973). Consequently, some models suggest a two-phased exhumation in the Cretaceous and Miocene (Grobe et al., 2018; Searle, 1985, 2007), in agreement with thermochronological constraints and an interpreted two-stage cooling with possible reheating in the late Miocene (Poupeau et al., 1998; Saddiqi et al., 2006). More recent studies, however, have shown that the data can also be explained by a cooling-only scenario with exhumation in the Eocene (Hansman et al., 2017). This is in agreement with recent structural observations suggesting early dome formation and later amplification of the structure (Grobe et al., 2018).

\subsection{Stratigraphic sequence}

Sediments in the Jebel Akhdar consist of a pre-Permian sequence (Autochthon A, Fig. 3) unconformably overlain by a Permian-Mesozoic sequence (Autochthon B, Fig. 3; Beurrier et al., 1986; Breton et al., 2004; Glennie et al., 1974; Rabu et al., 1990). During the Late Cretaceous, Hawasina nappes and the Semail Ophiolite were emplaced onto the passive margin, and neo-autochthonous rocks of Cenozoic age were deposited on top of the ophiolite after obduction (Béchennec et al., 1988; Forbes et al., 2010; Loosveld et al., 1996).

Autochthon A deposits are exposed in the Jebel Akhdar window down to the Mistal Fm. (Beurrier et al., 1986). Black limestones of the Hajir Fm., mudstone-rich carbonate beds of the Mu'aydin Fm., and limestone and dolostones of the Kharus Fm. conformably overlie the Mistal Fm. (Beurrier et al., 1986; Glennie et al., 1974). Platform breakup is recorded by laminated cherts and volcanoclastics of the Fara Fm. (Beurrier et al., 1986) followed by an unconformity representing a gap from Cambrian to Permian times (Loosveld et al., 1996). After the establishment of the Neotethyan Ocean during the Permian, northern Oman returned to stable passive margin conditions and the carbonate platform of the Autochthon B developed, with the Akhdar Group at its base (Koehrer et al., 2010; Pöppelreiter et al., 2011). This is unconformably overlain by limestones with clastic interlayers of the Jurassic Sahtan Group (Beurrier et al., 1986; Pratt et al., 1990). Limestones with marly, frequently organic-rich intercalations of the Cretaceous Kahmah (Al Habsi et al., 2014; Vahrenkamp, 2010) and Wasia groups (Grelaud et al., 2006; Homewood et al., 2008; Philip et al., 1995) form the youngest platform sediments (Robertson, 1987; Warburton et al., 1990).
The obduction-related moving forebulge and associated uplift ended passive margin deposition and eroded the topmost Wasia Group (Natih Fm.) in the Jebel Akdhar (Fig. 3) and deeper in the Saih Hatat region. Deposition in the foredeep basins in front of and behind the forebulge was dominated by the syn- and post-orogenic, conglomerate-rich sediments of the Muti Fm. and Aruma Group (Beurrier et al., 1986; Robertson, 1987). Towards the south, in the Adam Foothills, this laterally grades to calcareous foreland sediments of the Fiqa Fm. (Forbes et al., 2010; Robertson, 1987; Warburton et al., 1990).

Hawasina sediments accreted in front of and beneath the ophiolite represent marine slope and basin facies time equivalent to the Autochthon B (Béchennec et al., 1990). They are defined as four age-equivalent groups (Hamrat Duru, Al Aridh, Kawr, and Umar) representing carbonatic turbidite deposits (Hamrat Duru Group), radiolarian cherts and platform carbonates (Al Aridh Group), platform carbonates (Kawr Group), and interbedded carbonates and volcanics (Umar Group, Béchennec et al., 1990). After obduction of oceanic crust onto the passive margin, neo-autochthonous evaporites and carbonates of the Paleocene to Eocene Hadhramaut Gp. and bivalve-rich dolomites and limestones of the Oligoto Pliocene Fars Group were deposited south of the mountains (Béchennec et al., 1990; Forbes et al., 2010). Paleogeographic reconstructions show that the Oman mountains had high relief after obduction, followed by a low-relief landscape until the early Eocene (Nolan et al., 1990). In the middle Eocene marine transgression caused widespread deposition of limestones, as witnessed by the Seeb and Ruwaydah formations (Nolan et al., 1990). Post-Eocene times show renewed relief development and continued uplift until recent times (Glennie et al., 1974; Searle, 2007).

\subsection{Previous paleothermal data of the autochthon}

Only limited paleotemperature data are available from the carbonate platform (Fink et al., 2015; Grobe et al., 2016; Holland et al., 2009b; Stenhouse, 2014). Peak burial temperatures of $226-239^{\circ} \mathrm{C}$ for the top of the platform were measured using solid bitumen reflectance (also referred to as pyrobitumen reflectance) and Raman spectroscopy of carbonaceous material (RSCM) in the Jebel Akhdar indicate peak burial temperatures of 266 to $300^{\circ} \mathrm{C}$ for the entire platform (Grobe et al., 2016; Table 1). Temperature estimates based on RSCM and solid bitumen reflectance (Grobe et al., 2016) yielded similar temperatures for the southern flank of 248$280{ }^{\circ} \mathrm{C}$ for the Nahr Umr, 226-239 ${ }^{\circ} \mathrm{C}$ for the Natih B, and 172-206 ${ }^{\circ} \mathrm{C}$ for the Muti (Table 1, Fig. 3).

Vein crystallization temperatures of $166-205^{\circ} \mathrm{C}$ at the top of the Natih A (near Al Hamra) were measured by quartz-calcite thermometry in veins formed during ophioliteinduced burial (Gen. III of Grobe et al., 2018) and approximately $255^{\circ} \mathrm{C}$ for veins associated with a later normal fault network (Gen. V of Grobe et al., 2018; Stenhouse, 2014). 


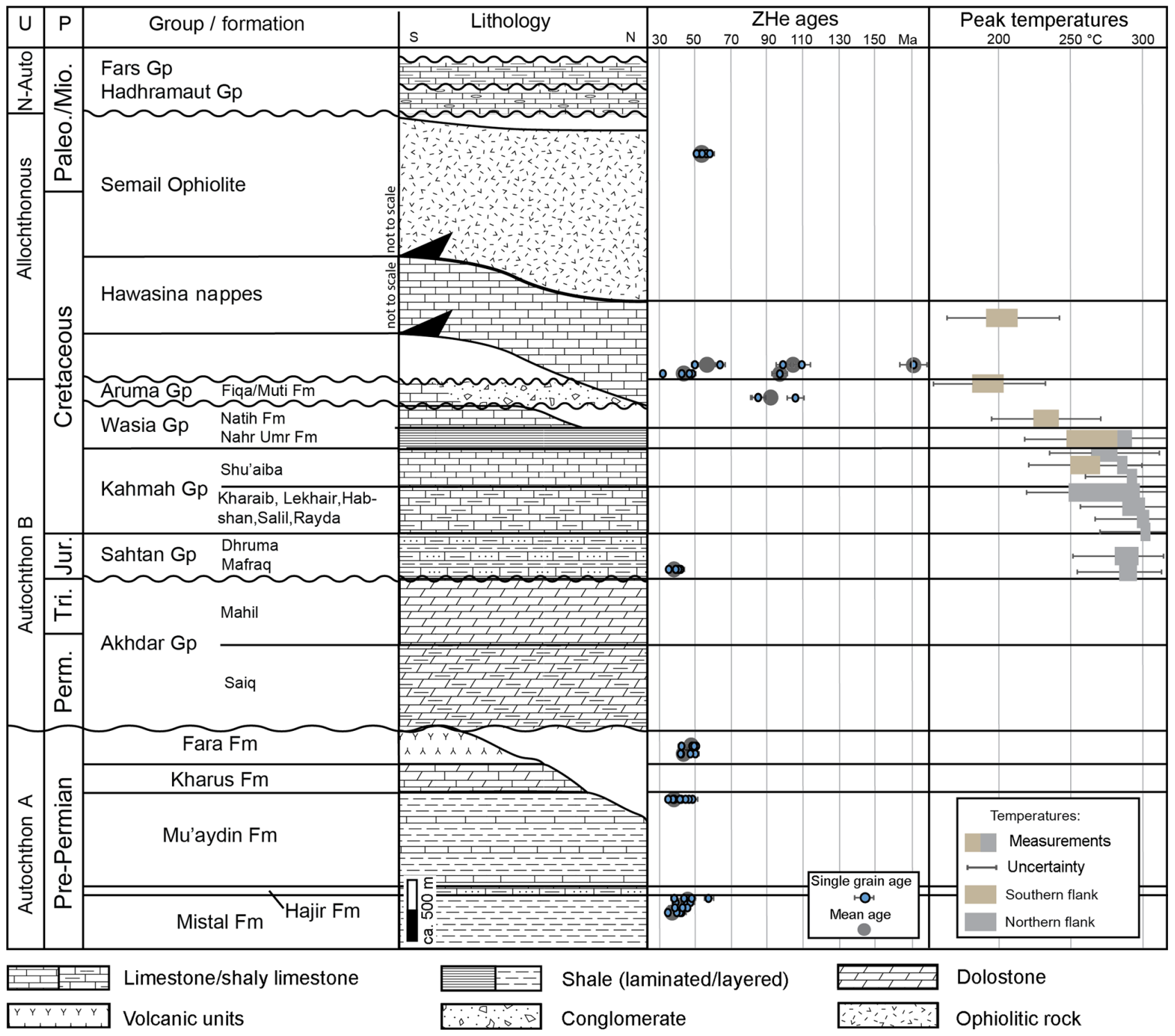

Figure 3. Stratigraphy of the Jebel Akhdar area with its two passive margin sequences Autochthon A and B overthrust by Hawasina and Semail nappes and unconformably overlain by neo-autochthonous units. Thermal calibration data are shown: ZHe ages (Table 2) show two different grain age clusters. Peak burial temperatures from organic matter maturity (Table 1) outline the temperature increase with stratigraphic age. Temperatures shown relate to the measurements and related uncertainties of the calculations (U: unit, P: period). Note that the Semail and Hawasina nappes are shown in their structural rather than stratigraphic positions; lithological data are compiled from Beurrier et al. (1986), Loosveld et al. (1996), Terken et al. (2001), and Forbes et al. (2010).

Fluid inclusions (FIs) of bedding-parallel pinch-and-swell veins (top-to-NNE shear after peak burial, Gen. IV of Grobe et al., 2018) show uncorrected minimum trapping temperatures of $134-221^{\circ} \mathrm{C}$ in the lower beds of the Sahtan Group at Wadi Nakhr (Holland et al., 2009b). Reflectance measurements of solid-bitumen-containing veins in the Wadi Ghul (Gen. I of Grobe et al., 2018), which are interpreted to be associated with fluid mobilization during forebulge migration, show maximum temperatures of $230^{\circ} \mathrm{C}$ (Fink et al., 2015).

Vitrinite reflectance data from Mozafari et al. (2015) show temperatures of ca. $140^{\circ} \mathrm{C}$ for the Natih B in the Jebel
Qusaybah, Adam Foothills, an area not overthrust by the ophiolite complex.

\subsection{Temperature evolution of the Semail Ophiolite nappe-allochthon}

Initial intra-oceanic ophiolite thrusting and associated metamorphism at its sole took place at peak temperatures of $840 \pm 70^{\circ} \mathrm{C}$ at $97-92 \mathrm{Ma}$ measured at several locations in the Oman mountains (Gnos and Peters, 1993; Hacker and Mosenfelder, 1996; Rioux et al., 2013; Searle and Cox, 2002; 
Warren et al., 2003). At 90-85 Ma the base of the ophiolite cooled to $350 \pm 50^{\circ} \mathrm{C}$ (white mica $\mathrm{Ar} / \mathrm{Ar}$ dating; Gnos and Peters, 1993). At around 80 Ma the deepest burial of the Oman margin beneath the ophiolite was reached (Hacker and Mosenfelder, 1996; Warren et al., 2005) with temperatures in the metamorphic sole below $300^{\circ} \mathrm{C}$ (Le Metour et al., 1990; Saddiqi et al., 2006). A lithospheric-scale thermomechanical model of the thrusting in northwestern Oman includes a thermal anomaly ca. $100 \mathrm{~km}$ northwest offshore of the Arabian margin to initiate subsea thrusting (Duretz et al., 2015).

\subsection{Petroleum system elements}

Several petroleum systems developed in the carbonate platform of northern Oman with important source rock horizons in the Natih Fm. (Members B and E). Both members contain Type I-II kerogen with total organic carbon contents up to $15 \%$ in the Natih B and up to $5 \%$ in the Natih E (Terken, 1999). Source rock maturity is restored based on biomarker analysis to ca. $0.7 \%$ VR within the Fahud reservoir and ca. $0.9 \%$ VR in the Natih reservoir (Terken, 1999). In the southern mountain foreland Natih oil generation started in the middle Cretaceous and continues until the present (Terken, 1999). Ophiolite obduction in the Jebel Akhdar area of northern Oman led to overmature Natih source rocks (Grobe et al., 2016). The Natih is classified as a supercharged, laterally drained, foreland petroleum system (Terken et al., 2001). However, the thermal impact of the moving forebulge and the importance of tectonic processes for fluid migration below and in front of the obduction orogen are not clear. At least three different generations of solid bitumen particles in veins and source rocks on the southern slope of the Jebel Akhdar suggest pulses of hydrocarbon generation and migration in front of the Oman mountains (Fink et al., 2015; Grobe et al., 2016). In central Oman, Shu'aiba and Tuwaiq oils are produced from the Kahmah and Sahtan Group reservoirs, sealed by argillaceous shales of the Nahr Umr Fm. (Terken et al., 2001). All these units are well exposed in the Oman mountains.

\section{Methods}

\subsection{Raman spectroscopy of carbonaceous material}

To determine levels of thermal maturity, over 100 dark, unweathered, and organic-rich samples were taken from different stratigraphic units in the Jebel Akhdar (Sahtan Group, Kharaib Fm., Shu'aiba Fm., Nahr Umr Fm., Natih Fm., Muti Fm.; Fig. 3). Based on total organic carbon (TOC) content as determined by Grobe et al. (2016), 13 samples were selected for thermal maturity analysis on surfaces cut perpendicular to bedding. Results were used to calibrate the peak burial temperatures of the numerical basin models. The organic particles lack sufficient size or surface qual- ity for reflectance measurements and are therefore investigated by confocal Raman spectroscopy of carbonaceous material. The technique measures vibrational energies of chemical bonds, which change during temperature-induced reorganization of amorphous carbonaceous material (kerogen) to graphite (e.g., Aoya et al., 2010; Beyssac et al., 2002; Kouketsu et al., 2014; Mair et al., 2018). Measurements were conducted at the Geoscience Center, Göttingen, on a Horiba Jobin Yvon HR800 UV spectrometer attached to an Olympus BX-41 microscope and a $100 \times$ objective. A highpower diode laser with a wavelength of $488 \mathrm{~nm}$ and an output power of $50 \mathrm{~mW}$ was installed and a D1 filter avoided sample alteration by heating. Each spectral window (center at $1399.82 \mathrm{~cm}^{-1}$, grid of 600 lines per $\mathrm{mm}$ ) was measured 5 to 10 times for 2 to $10 \mathrm{~s}$ with a Peltier CCD detector at activated intensity correction. For quality control, the $520.4 \mathrm{~cm}^{-1}$ line of a $\mathrm{Si}$ wafer was measured every $30 \mathrm{~min}$ without observable drift of the measurements. To transform the measured data into $\mathrm{VR}_{\mathrm{r}}$ values, the scaled total area (STA) approach of Lünsdorf (2016) was applied with the equation of Grobe et al. (2016):

$\mathrm{VR}_{\mathrm{r}}=-\frac{\mathrm{STA}-280.13}{24.71}[\%]$.

Absolute errors of the applied calibration are of the order of $\pm 40^{\circ} \mathrm{C}$. Based on comparing neighboring samples (Grobe et al., 2016), we can resolve the relative differences down to $\pm 30^{\circ} \mathrm{C}$, which also represents the residual error interpreted to relate to within-sample heterogeneity (Lünsdorf et al., 2017; Nibourel et al., 2018).

\subsection{Fluid-inclusion thermometry}

Doubly polished wafers (ca. $200 \mu \mathrm{m}$ thick) of four vein samples (FI-N1, FI-N2, FI-M1, FI-M2) have been prepared according to the procedure described by Muchez et al. (1994). Fluid-inclusion (FI) petrography and microthermometry were performed to analyze the temperaturepressure conditions and fluid salinity. FIs represent paleofluids accidentally trapped in a crystalline or amorphous solid during crystallization, lithification, or both (Diamond, 2003). If unaffected by later changes, trapping pressure and temperature are given by the homogenization temperature (Barker and Goldstein, 1990). Based on the time of trapping primary (mineral growth), secondary (fracture-related) and pseudosecondary inclusions are distinguished (Barker and Goldstein, 1990; Diamond, 2003; Goldstein, 2001; Van Den Kerkhof and Hein, 2001).

Two calcite vein samples of the Natih Fm. (FI-N1 and 2, locations in Fig. 4) represent conditions related to early burial (FI-N2, structural generation I of Grobe et al., 2018) and burial beneath the ophiolite (FI-N1, structural generation III of Grobe et al., 2018). Two quartz-rich calcite veins of the Muti Fm. (FI-M1 and 2, locations Fig. 4) are related to late NE-SW-striking strike-slip faults (generation IX of Grobe et 
al., 2018). FI assemblages were defined and fluid inclusions measured with a Linkam THMSG600 thermostage (accuracy $\pm 0.1{ }^{\circ} \mathrm{C}$ ) attached to an Olympus BX60 microscope at the $\mathrm{KU}$ Leuven, Belgium. Calibration was performed using $\mathrm{CO}_{2}, \mathrm{H}_{2} \mathrm{O}-\mathrm{NaCl}, \mathrm{H}_{2} \mathrm{O}-\mathrm{KCl}$, and $\mathrm{H}_{2} \mathrm{O}$ standards. Homogenization temperatures $\left(T_{\mathrm{h}}\right)$ were measured prior to temperatures of complete freezing $\left(T_{\mathrm{f}}\right)$, first melt $\left(T_{\mathrm{fm}}\right)$, and complete melting of ice $\left(T_{\mathrm{m} \text { (ice) }}\right)$ to avoid stretching or leakage due to the volume increase during ice formation. All measured temperatures were recorded during heating, except for the freezing temperature $\left(T_{\mathrm{f}}\right)$. Pressure corrections of $T_{\mathrm{h}}$ were conducted with the program FLINCOR (Brown, 1989) for 280 and $340 \mathrm{MPa}$, assuming 8 to $10 \mathrm{~km}$ of ophiolite overburden (see model results, $\rho=\mathrm{ca} .3070 \mathrm{~kg} \mathrm{~m}^{-3}$ ) and $2 \mathrm{~km}$ of Hawasina nappes $\left(\rho=\right.$ ca. $\left.2450 \mathrm{~kg} \mathrm{~m}^{-3}\right)$, and for $45 \mathrm{MPa}$, assuming $2 \mathrm{~km}$ of sedimentary overburden (Al-Lazki et al., 2002; Grobe et al., 2016). Fluid salinities were calculated from the $T_{\mathrm{m} \text { (ice) }}$ values considering an $\mathrm{H}_{2} \mathrm{O}-\mathrm{NaCl}$ composition (Bodnar, 1993), which is based on the $T_{\mathrm{fm}}$ values.

\subsection{Thermochronometry}

Zircon $(\mathrm{U}-\mathrm{Th}) / \mathrm{He}(\mathrm{ZHe})$ dating allows us to reconstruct the thermal history of the topmost few kilometers of the Earth's crust. Helium retention in less metamict zircon crystals is sensitive in the temperature range between ca. 130 and $170^{\circ} \mathrm{C}$, i.e., the zircon partial retention zone (PRZ; Reiners, 2005). A total of 11 rocks sampled above (Muti Fm., Matbat Fm. of the Hamrat Duru Group, and Trondjemite of the Semail nappes), below (Mistal Fm., Muaydin Fm., Fara Fm.), and within (Sahtan Gp.) the carbonate platform were selected for ZHe dating. Zircon crystals were released using high-voltage pulse crushing (http://www.selfrag.com) and concentrated by standard mineral separation processes (drying, dry-sieving, magnetic and heavy liquid separation). Three to eight clear, intact, euhedral single crystals were selected per sample and transferred into platinum microcapsules. They were degassed under high vacuum by heating with an infrared diode and extracted-gas-purified using a SAES Ti-Zr getter at $450^{\circ} \mathrm{C}$. Helium was analyzed with a Hiden triple-filter quadrupole mass spectrometer. Degassed zircons were subsequently dissolved in pressurized teflon bombs and spiked, and then $\mathrm{U}$, Th, and Sm were measured with a Perkin Elmer Elan DRC II ICP-MS equipped with an APEX micro-flow nebulizer.

Time-temperature histories were reconstructed using the HeFTy 1.8.3 software package (Ketcham, 2005) applying the kinetic zircon properties of Guenther et al. (2013). For samples with reset zircons the only constraint used was a minimum temperature above $200^{\circ} \mathrm{C}$ between deposition and the calculated ZHe age. Thermal modeling was conducted until 100 statistically good time-temperature paths were achieved (goodness of fit: 0.5, value for acceptable fit: 0.05). In cases in which this was not possible, at least 10000 independent paths were calculated.

\subsection{Numerical basin modeling}

Structural evolution was palinspastically reconstructed starting from the present-day profile using Move 2D (2016.1, Midland Valley Exploration). Geometries and relative ages of the structures were supplemented with subsurface data (Al-Lazki et al., 2002; Filbrandt et al., 2006; Searle et al., 2004; Warburton et al., 1990). The reconstruction workflow is based on restoring the pre-deformation layer continuity as follows: (1) faulted layers in the southern foreland were restored, and (2) doming was retro-deformed by vertical simple shear before (3) normal faults in the Jebel Akhdar were restored. This sequence is based on our tectonic model (Grobe et al., 2018). The resulting geometries were used as pre-thrusting input geometries for 2-D PetroMod 2014.1 (Schlumberger) basin modeling, enabling thermal maturity reconstruction for vitrinite reflectance values of $0.3 \%$ to $4.7 \%$ by the use of the EASY \% Ro approach (Sweeney and Burnham, 1990). The numerical basin model is based on a conceptional definition of events. Based on this sequence of events (sedimentation, erosion, hiatus) a forward, event-stepping modeling was performed, starting with the deposition of the oldest layer. Subsequent deposition and burial is leading to differential compaction of the single rock units. For each event, lithologies and related petrophysical rock properties were assigned (Figs. S1, S2 in the Supplement).

For our conceptual model the following sequence of events was implemented (Fig. 3): (1) passive margin carbonate sedimentation from Permian until late Cenomanian times (Forbes et al., 2010; Loosveld et al., 1996) interrupted by a short erosional period at the Triassic-Jurassic boundary (Koehrer et al., 2010; Loosveld et al., 1996); (2) a moving forebulge associated with a paleo-water depth increase in its foredeep and erosion of the top of the carbonate platform in the north of the transect (Robertson, 1987); (3) the emplacement of allochthonous sedimentary nappes; and (4) subsequent stepwise obduction of the ophiolite with deepest burial reached at ca. $79 \mathrm{Ma}$ (Warren et al., 2005). Modeling ophiolite obduction as rapid emplacement accounts for burial-related heat effects in the carbonate platform underneath but does not allow us to fully restore the temperatures within the ophiolitic or sedimentary nappes. The area of the Adam Foothills, represented in the transect by Jebel Qusaybah, is a relic of the moving forebulge not overthrust by allochthonous units this was used to calibrate the burial depth of the foredeep at this point in the transect. The area to the south of the Adam Foothills is unaffected by foredeep sedimentation, but also lacks thermal calibration data. Absolute ages, thicknesses, lithologies, and related petrophysical properties as well as source rock properties were associated according to the results of our own field mapping and the compiled data from Forbes et al. (2010; Fig. S1).

Thermal boundary conditions of the model have been defined for each time step by the basal heat flow (HF) and 
the sediment-water interface temperature (SWIT), representing the upper thermal boundary (Fig. S3). To account for active margin tectonics and uplift and exhumation of the Jebel Akhdar, we assume an increase in basal heat flow since the Late Cretaceous. The resulting heat flow trend (Fig. S3, Terken et al., 2001; Visser, 1991) has been assigned to the entire transect and was tested in the sensitivity analysis. Paleosurface temperatures were estimated based on Oman's paleolatitude (after Wygrala, 1989) corrected by the effect of the paleo-water depth (PWD) derived from the facies record (Van Buchem et al., 2002; Immenhauser et al., 1999; Immenhauser and Scott, 2002; Koehrer et al., 2010; Pratt et al., 1990; Robertson, 1987). This assumes that a possible heat source from the ophiolite itself does not significantly affect the temperature evolution of the top of the carbonate platform (see Discussion section).

This setup has been iterated until modeling results fit the thermal calibration data (Table 1). From $\mathrm{VR}_{\mathrm{r}}$ calculations peak burial temperatures were determined following the approach of Barker and Pawlewicz (1994). For calibration of the numerical basin models, data were supplemented by thermal maturity and peak burial temperature data from 63 Natih B source rock samples taken around the Jebel Akhdar Dome (Grobe et al., 2016) and data from the Adam Foothills on Jebel Qusaybah (Mozafari et al., 2015).

Main modeling uncertainties derive from uncertainty in the thickness of the paleo-overburden (Muti Fm., Ophiolite, Hawasina nappes) and uncertainty of the paleo-basal heat flow. Present-day heat flow was calibrated by data and borehole temperatures from Visser (1991) and Rolandone et al. (2013), and peak burial temperatures were determined by Raman spectroscopy and solid bitumen reflectance data (Table 1). From surface samples and their position in the stratigraphic column, various pseudo-wells were created (e.g., Nöth et al., 2001) and used as control points for the 2-D model (Fig. 2). The model was used for sensitivity analyses of different input parameters.

\section{Results and interpretation}

\subsection{Thermal maturity and host rock burial temperatures}

New Raman spectroscopy data on the northern flank are shown in Table 1 and give scaled total areas of 78-172. This corresponds to peak temperatures of $270-300^{\circ} \mathrm{C}$ in the Shu'aiba Fm., $268-305^{\circ} \mathrm{C}$ in the Kahmah Group, $283-$ $286^{\circ} \mathrm{C}$ in the Sahtan Group, $270-288^{\circ} \mathrm{C}$ in the Nahr Umr Fm., and ca. $266^{\circ} \mathrm{C}$ at the base of the Natih Fm. Based on the calculation to $\mathrm{VR}_{\mathrm{r}}$ and temperature an absolute error of $\pm 30^{\circ} \mathrm{C}$ has to be considered for the single values. Thermal maturity data on the Natih Fm. show solid bitumen reflectances of $2.95 \%-3.72 \%$ for the southern flank of the Jebel Akhdar (Fink et al., 2015; Grobe et al., 2016), 3.32\%
BR for the northern flank (Grobe et al., 2016), and a single measurement of $1.1 \%$ VR for the Jebel Qusaybah (Mozafari et al., 2015).

Calculated peak temperatures for the autochthonous Cretaceous deposits in the Jebel Akhdar range between 225 and $305^{\circ} \mathrm{C}\left( \pm 30^{\circ} \mathrm{C}\right.$, error of the calibration), with two Jurassic samples at 283 and $286^{\circ} \mathrm{C}\left( \pm 30^{\circ} \mathrm{C}\right)$. Temperatures are generally higher on the northern flank (gray boxes, Fig. 3) of the Jebel Akhdar and slightly increase with stratigraphy in the autochthons. Samples from the Muti Fm. (178-208 $\left.\pm 30^{\circ} \mathrm{C}\right)$ and the Hawasina nappes $\left(193-213 \pm 30^{\circ} \mathrm{C}\right)$ show lower temperatures compared to the autochthons. A single sample from the Jebel Qusaybah reflects peak temperatures of ca. $140^{\circ} \mathrm{C}$ (Table 1) in an area that was not overthrusted by nappes but buried in the related moving forebulge.

\subsection{Thermochronology}

Results of the ZHe dating are shown in Figs. 3 and 4; timetemperature paths modeled with HeFTy are included in the Supplement (Figs. S4 and S5). Samples from the carbonate platform (stratigraphically older than the Muti Fm.) have been entirely reset after deposition, as witnessed by Neogene apparent ages. Similarly, cooling ages from the center of the Jebel Akhdar Dome fall in the range of $48.7 \pm 1.8$ to $39.8 \pm 3.0 \mathrm{Ma}$ (Table 2, Fig. 4). Sample T4, collected in the Muti Fm., yields an apparent mean age of $93.8 \pm 6.9 \mathrm{Ma}$ and samples T5 and T7 of the Hawasina nappes collected at the northern and the southern slope of the dome show two grain age clusters of $43.0 \pm 3.7 / 99.2 \pm 8.5 \mathrm{Ma}$ and $58.9 \pm$ 7.0/106.0 $\pm 5.2 \mathrm{Ma}$, respectively. In sample T5, an additional single grain age of $172.9 \pm 14.9$ Ma was obtained.

These ages indicate a large-scale cooling signal that affects the entire Jebel Akhdar area; the ZHe age pattern and 1-D thermal models indicate a phase of rapid cooling below $170{ }^{\circ} \mathrm{C}$ in the early Cenozoic (58.9 \pm 7.0 and $\left.39.8 \pm 3.0 \mathrm{Ma}\right)$. The range of modeled cooling paths outline maximum cooling rates of $2-8{ }^{\circ} \mathrm{CMyr}^{-1}$. This is followed by slower cooling until the present day.

Data from the Muti Fm. and the Hawasina units differ partly from this trend: the apparent $\mathrm{ZHe}$ ages of clasts in the Muti sample T4 (mean: $93.8 \pm 6.9 \mathrm{Ma}$ ) are as old as its respective stratigraphic age (Robertson, 1987). Even though all ages reproduce within error, this indicates partial reset of the $\mathrm{ZHe}$ system, as post-depositional reheating above closure temperature would result in younger ages. Samples from the lower Hawasina nappes contain two grain age clusters. Older ages coincide with higher uranium concentrations, suggesting that only the younger ages represent thermally reset zircons. We note that the older ZHe ages of 110-95 Ma coincide with the timing of forebulge migration through the area, as independently determined in the stratigraphic record by the Wasia-Aruma break (Fig. 3). This may be either pure coincidence due to partial resetting of an older grain age population, or it may be a grain age population with higher closure 


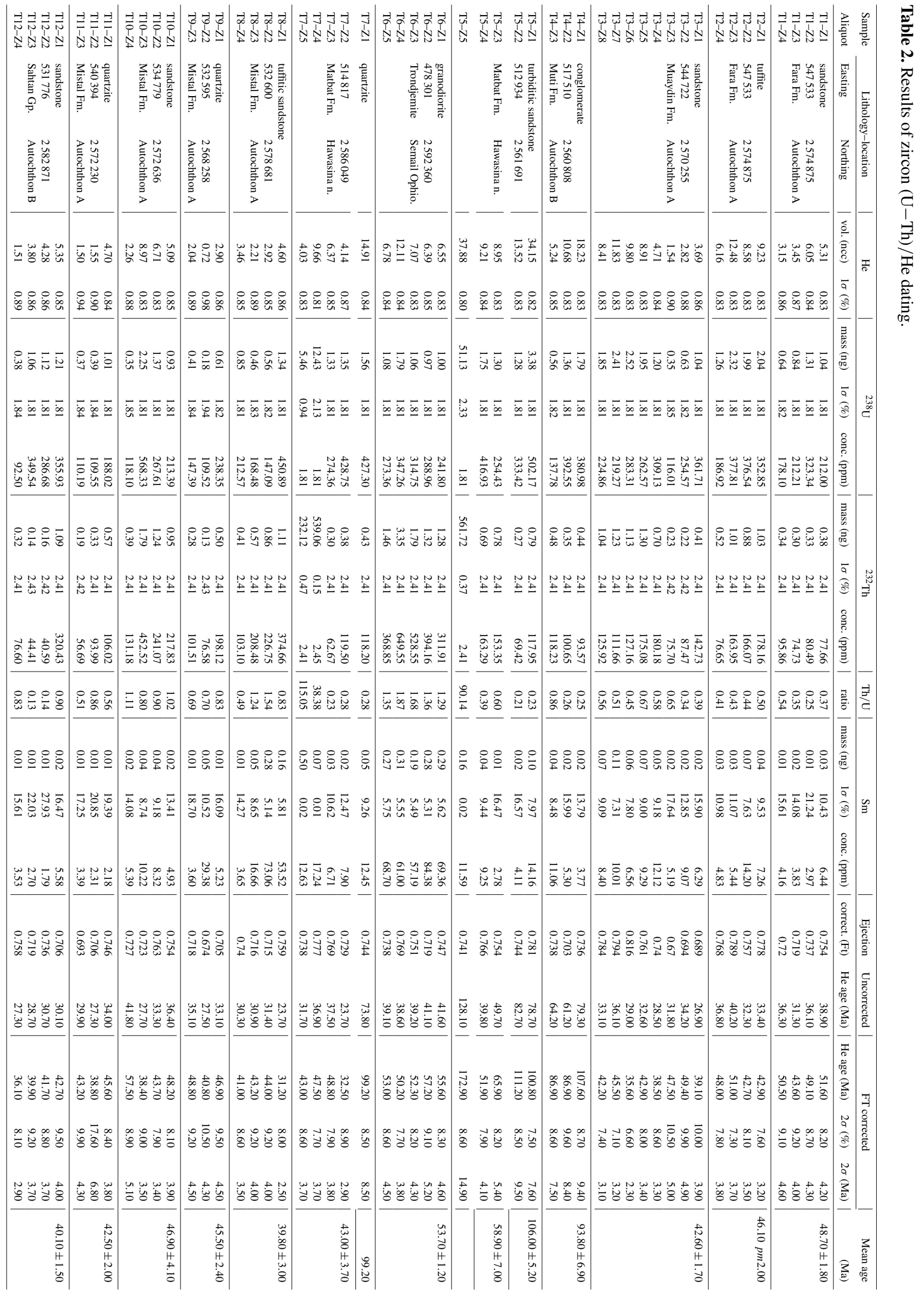




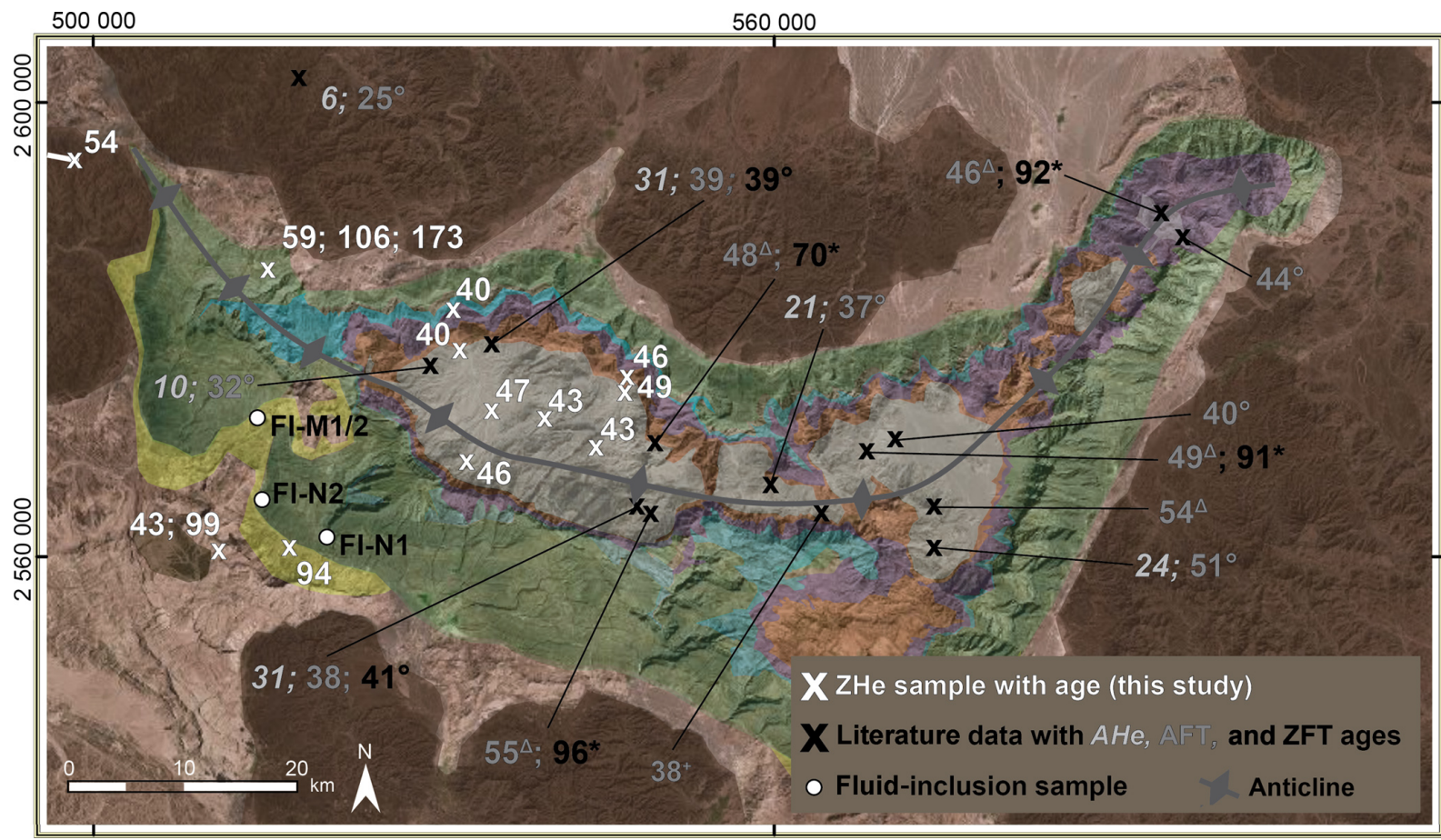

Figure 4. Map view of ZHe ages (in Ma). Data outline a general cooling between $58.9 \pm 7.0$ and $39.8 \pm 3.0$ Ma. Some samples outside of the dome show two age clusters, with an additional age of ca. $100 \mathrm{Ma}$. Additional temperature data refer to zircon fission track ages from (*) Saddiqi et al. (2006), apatite fission track ages from ( $\Delta$ ) Poupeau et al. (1998) and (+) Mount et al. (1998), and AHe, AFT, and ZFT ages from $\left({ }^{\circ}\right.$, gray) Hansman et al. (2017). Moreover, the locations of samples used for fluid-inclusion measurements are shown. Colors in the background depict geological units (brown: ophiolite, pink: Hawasina units, light green: Muti Fm., dark green: Wasia and Kahmah Gp., blue: Sahtan Gp., purple: Mahil Fm., orange: Saiq Fm., gray: pre-Permian, shaded DEM from Esri, Digital Globe, swisstopo, and the GIS user community).

temperature witnessing exhumation. We discuss the reasons for different resetting temperatures below. However, partial reset of $\mathrm{ZHe}$ ages suggests that the Hawasina samples have not experienced temperatures exceeding the partial retention zone (PRZ) of $130-170^{\circ} \mathrm{C}$.

A sample from an intrusive body of the Semail Ophiolite yields ZHe ages of $53.7 \pm 1.2 \mathrm{Ma}$ (T6) with a modeled cooling path gradually decreasing into the PRZ until ca. $55 \mathrm{Ma}$. This time interval of passing the PRZ is comparable to the Hawasina nappe samples beneath the ophiolite but occurs slightly earlier than cooling of the autochthons. Nevertheless, Semail Ophiolite, Hawasina nappes, and the autochthonous margin sequence were affected by the same cooling event that was possibly initiated by exhumation of the Jebel Akhdar Dome.

\subsection{Fluid inclusions}

The Muti vein samples FI-M1 and M2 of the southern Jebel Akhdar show evidence of crack and seal processes (youngest parts in the center of the vein; Ma-2010-11b and 14a of Arndt, 2015) with blocky quartz grains that contain two kinds of roundish primary FIs with sizes of 3-20 $\mu \mathrm{m}$. They are mainly aligned along dark zones and are interpreted as growth zones or form bright clusters in the central part of the crystals. A third set of fluid inclusions (FIs) appears in large, grain-crosscutting trails interpreted to be of secondary origin. Calcite crystals within the Natih veins contain bright FIs with sizes of $2-20 \mu \mathrm{m}$ and are edgy, often rectangular, or trapezoidal in shape. Identified primary FIs are aligned parallel to crystal growth zones.

All measured FIs are two-phase liquid-vapor inclusions with ice as the last phase to melt. The Muti samples show $T_{\text {fm(ice) }}$ between $-5.1 \pm 0.5$ and $-4.6 \pm 0.3^{\circ} \mathrm{C}$ and $T_{\text {m(ice) }}$ at $-2.2 \pm 0.2$ to $-1.9 \pm 0.1^{\circ} \mathrm{C}$, and the Natih sample has $T_{\mathrm{fm}}$ of $-18.4 \pm 1.9$ to $-20.2 \pm 2.1^{\circ} \mathrm{C}$ and $T_{\mathrm{m} \text { (ice) }}$ of $-7.1 \pm 0.3$ to $-8.9 \pm 1.8^{\circ} \mathrm{C}$ (Table 3 ). The first melting temperatures of all inclusions correspond to an $\mathrm{H}_{2} \mathrm{O}-\mathrm{NaCl}$ system, and complete melting temperatures of ice indicate salinities similar to seawater $(3.0 \pm 0.5$ wt. $\%$ to $3.5 \pm 0.3$ wt. $\% \mathrm{NaCl}$ eq., Muti Fm.; Fig. S6) or 3 times higher (10.3 \pm 0.3 wt. $\%$ to $12.5 \pm 2.0$ wt. $\%$ $\mathrm{NaCl}$ eq., Natih Fm.; Fig. S6).

Primary inclusions in quartz crystals from the Muti Fm. show minimum trapping temperatures of $161 \pm 3$ to $166 \pm 7^{\circ} \mathrm{C}$ (Table 3; FI-M2 and middle of FI-M1) with a second primary population of $189 \pm 3{ }^{\circ} \mathrm{C}$ (sides of vein FI-M1). $T_{\mathrm{h}}$ values of secondary inclusions in FI-M1 are above $200^{\circ} \mathrm{C}$. 
8 를. 융

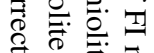

बे

जे छ.

훙 융

융

要

․․ㄹ.

․ㅡㄹ. 를. 를

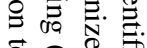

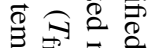

焉实

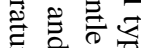

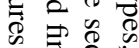

*

है

ब्ञ

大

글

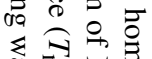

.

$\Longleftarrow 0$

웅

$\overrightarrow{0}$ \%

प्त्र

के क

声芯后

政 $\cong$

施

范

류 फ

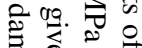

ซึ ?

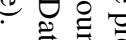

可

$\triangle$ 웅

응

产

\& 0 응

$\because$

佮

앙

:

象是

各官

웅

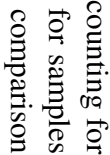


In sample FI-M2, two generations of secondary inclusions were observed, both reflecting lower $T_{\mathrm{h}}$ than the primary inclusions. No hints of necking down, leakage, or stretching were observed at the measured inclusions and over $90 \%$ of the measured FIs in one assemblage are in the range of $10-15^{\circ} \mathrm{C}$, representing a good quality of the measurements (Goldstein, 2001).

Samples FI-N1 and N2 from the Natih Fm. in the southern Jebel Akhdar (Fig. 4) contain primary inclusions hosted by calcite crystals giving $T_{\mathrm{h}}$ of $80 \pm 4,90 \pm 5$ and $114 \pm$ $7{ }^{\circ} \mathrm{C}$ (Table 3). The latter population is often characterized by elongated, possibly stretched FI and is not considered for further interpretations. Assuming vein formation during burial (Grobe et al., 2018; Hilgers et al., 2006; Holland et al., 2009b; Virgo, 2015) under 8 to $10 \mathrm{~km}$ of ophiolite, including partially serpentinized peridotite and $2 \mathrm{~km}$ of Hawasina nappes, results were pressure-corrected for 280 and $340 \mathrm{MPa}$, leading to corrected homogenization temperatures of $235 \pm 5$ and $266 \pm 5{ }^{\circ} \mathrm{C}$ (FI-N1) and $225 \pm 4$ and $256 \pm 4{ }^{\circ} \mathrm{C}$ (FI-N2; Table 3 ). Signs of strong deformation such as twinning or cleavage were not observed in the measured inclusions; secondary inclusions were present but not measured.

These temperatures represent minimum trapping conditions of a paleofluid and do not necessarily represent burial temperatures of the host rock. It should be noted that the analyzed Natih veins formed bedding confined (Grobe et al., 2018; Holland et al., 2009b; Virgo, 2015) and show host-rock-buffered carbonate isotope signatures (Arndt et al., 2014; Hilgers et al., 2006). This corroborates the idea that the analyzed veins were in thermal equilibrium with their host rocks.

FI microthermometry of late strike-slip veins in the Muti Fm. are interpreted to have formed after dome formation (Grobe et al., 2018; Virgo, 2015) at an assumed minimum depth of $2 \mathrm{~km}$ (preserved allochthonous thickness). A pressure correction for the related $45 \mathrm{MPa}$ corresponds to minimum fluid trapping temperatures of $184 \pm 3{ }^{\circ} \mathrm{C}$ (FI-M2) and $213 \pm 3^{\circ} \mathrm{C}$ (FI-M1) with a later phase of primary inclusions outlining $189 \pm 7^{\circ} \mathrm{C}$ and even cooler secondary inclusions of $138 \pm 12$ to $172 \pm 2{ }^{\circ} \mathrm{C}$ (FI-M1 and M2; Table 3 ). These cooler fluid temperatures can be explained by further exhumation of the Jebel Akhdar and hence cooling of the fluid reservoir during crack-seal vein formation. Isotope studies on the vein calcite do not support an open system with fluid exchange (Stenhouse, 2014; Virgo and Arndt, 2010); hence, we interpret the formation of strike-slip-related veins as having formed during exhumation following peak burial.

Based on the assumption that fluid and host rock were in thermal equilibrium, we can use maturity data in combination with fluid-inclusion data to estimate the pressure at vein formation. Peak temperatures of the Sahtan Group revealed by RSCM reached $283 \pm 9$ to $286 \pm 6^{\circ} \mathrm{C}$ (Table 1, Fig. 5 red line) and enable us to solve the pressure-temperature couples of FIs measured in Sahtan veins formed at deepest burial by

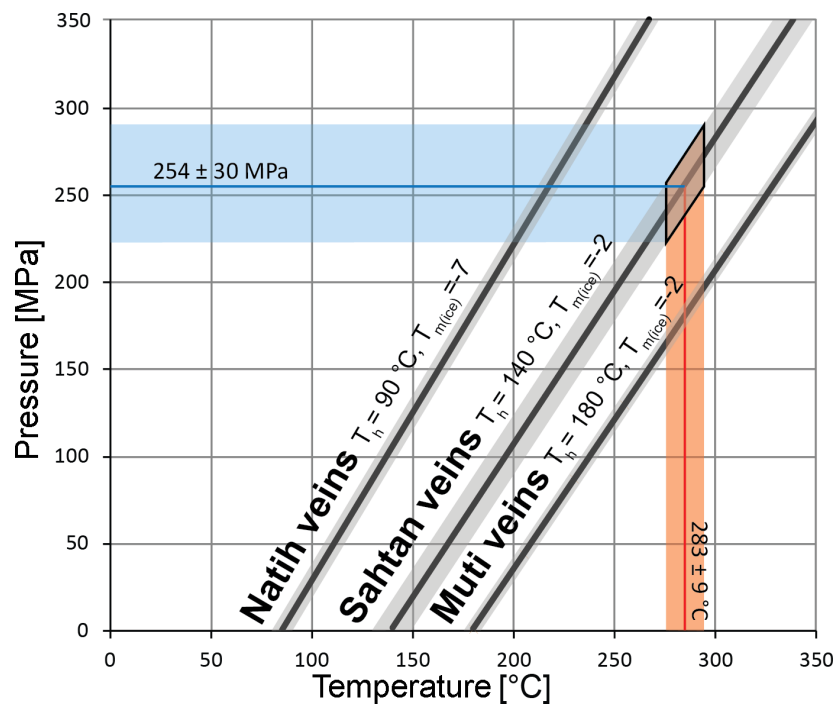

Figure 5. Fluid-inclusion isochores (solid black lines) of analyzed fluid-inclusion populations with corresponding standard deviations (shaded areas; for Sahtan Group data from Holland et al., 2009b, conservatively $\pm 10^{\circ} \mathrm{C}$ are assumed). To estimate the pressure conditions during vein formation, calculated temperatures from thermal maturity data are added for the Sahtan Group (red line with error) and result in minimum trapping pressures of $254 \pm 30 \mathrm{MPa}$ during peak burial (blue line with error).

Holland et al. (2009b, black line). This results in minimum trapping pressures of $254 \pm 30 \mathrm{MPa}$ at times of vein formation (Fig. 5 blue line), which correspond to times close to or at deepest burial of the carbonate platform.

\subsection{Basin modeling}

Numerical basin modeling integrates all data and tests the individual interpretations in the thermal and geodynamic framework. Deepest burial was constrained with thermal maturity data and exhumation with thermochronological data. In the following we present our best-fit model, considering a mixed ophiolite lithology (Searle and Cox, 2002) consisting of strongly serpentinized peridotites. Then, the sensitivity of important results to changes in relevant input parameters are discussed.

Modeled evolution of the transect over time is given in Figs. 6 and 7, showing (a) final deposition of the Autochthon B, (b) erosion of the Natih Fm. in the north by a moving foredeep (no erosion in $\mathrm{S}$, full erosion in $\mathrm{N}$ ), (c) emplacement of $1400 \mathrm{~m}$ of the Hawasina nappes, and (d)-(e) ophiolite obduction reconstructed by rapid, stepwise sedimentation. After maximum burial beneath the ophiolite complex at ca. $80 \mathrm{Ma}$ (Warren et al., 2005) exhumation is assumed to start slightly prior to $55 \mathrm{Ma}$ (Saddiqi et al., 2006) with a rapid phase of cooling below ca. $200^{\circ} \mathrm{C}$ at $55 \mathrm{Ma}$, leading to lower temperatures in the Jebel Akhdar region. 1- 
D burial plots of two pseudo-wells created from point data in Wadi Nakhr and Wadi Yiqah are shown in Fig. 8.

As a model setup only presents one possible solution out of several, sensitivity analyses with varying paleo-overburden thicknesses (Figs. 9 and 10), changing degrees of serpentinization of the ophiolite, and varying basal heat flow during deepest burial (Fig. 11) are presented and discussed below.

Thermal maturity data on the Natih B at Jebel Qusaybah $\left(1.1 \% \mathrm{VR}_{\mathrm{r}}\right)$, Adam Foothills, require peak temperatures of ca. $140{ }^{\circ} \mathrm{C}$ (Table 1). Sensitivity analyses of the overburden above the Natih Fm. show that a maximum of $4 \mathrm{~km}$ of sedimentary overburden (Figs. 9a and 10a) is needed to match the calibration data (Figs. 9a and 10a).

To restore the former minimum thickness of the Semail Ophiolite, the thickness of the Hawasina nappes along the transect was fixed to $2 \mathrm{~km}$, as suggested by the maximum present-day thickness of the Jebel Misht exotics. To reach the required thermal conditions measured at the entrance of the Wadi Nakhr (Natih B: 2.83-3.72\% VR, $225-260{ }^{\circ} \mathrm{C}$; Grobe et al., 2016), $8-10 \mathrm{~km}$ of the original total thickness of strongly serpentinized ophiolite sequence are needed in addition to the $2 \mathrm{~km}$ of Hawasina nappes (Figs. $9 \mathrm{~b}$ and 10b). These thicknesses are also sufficient to reach peak temperatures calculated for older stratigraphy at the northern flank of the Jebel Akhdar Dome (Shu'aiba Fm. at Wadi Yiqah: 270$295^{\circ} \mathrm{C}$ by RSCM; Figs. 9c and 10c). Modeling results show an earlier heating and more rapid increase in maturity in the north. We associate this with the $2 \mathrm{Myr}$ earlier onset of obduction and hence a longer burial of the northern carbonate platform (Wadi Yiqah) under the active ophiolite obduction compared to its southern counterpart (Béchennec et al., 1990; Cowan et al., 2014).

Another factor influencing the modeling results is related to the lithology of the overburden and its compaction. In the special case of burial under an ophiolite, serpentinization of peridotite and its impact on ophiolite density and thermal conductivity must be considered. Sensitivity analysis of ophiolite serpentinization shows the temperature and thermal maturity effects on our model (Fig. 11). A model case of ophiolite without any serpentinized peridotite $(0 \%$ case, $\rho_{\text {ophio }}=3133 \mathrm{~kg} \mathrm{~m}^{-3}$ ) would represent the largest deviation compared to our best-case model assuming complete ophiolite serpentinization $\left(100 \%\right.$-case, $\left.\rho_{\text {ophio }}=3069 \mathrm{~kg} \mathrm{~m}^{-3}\right)$. This density is based on Al-Lazki et al. (2002). Even if the upper part of the ophiolite was missing in the Jebel Akhdar area (Nicolas and Boudier, 2015), this and the field data from Searle and Cox (2002) in the Saih Hatat support strong serpentinization. A less serpentinized ophiolite means higher densities and related higher thermal conductivities of the overburden and thus lower peak temperatures in the sediments below. In the case of no serpentinization, the peak temperature of Natih B in the Wadi Nakhr would decrease by ca. $60^{\circ} \mathrm{C}$, resulting in a maximum thermal maturity decrease of $1.5 \% \mathrm{VR}$. The best-fit model with an ophiolite thickness of $8-10 \mathrm{~km}$ would need an additional $3 \mathrm{~km}$ of overburden at $0 \%$ serpentinization to equally match the measured thermal maturities. Additional thicknesses of $0.75 \mathrm{~km}(75 \%$ serpentinization), $1.5 \mathrm{~km}$ (50\% serpentinization), and $2.25 \mathrm{~km}$ ( $25 \%$ serpentinization) apply for lower degrees of serpentinization (compare to Fig. 9).

Results depend strongly on basal heat flow (Fig. S3). The best-fit model of $40 \mathrm{~mW} \mathrm{~m}^{-2}$ at maximum burial is typical for a passive continental margin setting. If this heat flow at peak burial were lowered to $30 \mathrm{~mW} \mathrm{~m}^{-2}$ an additional $1.2 \mathrm{~km}$ of ophiolitic overburden would be required to achieve a match with thermal calibration data (Fig. 11). Increased heat flow values to 50,60 , or $70 \mathrm{~mW} \mathrm{~m}^{-2}$ would result in lowering of overburden by $1.3,2.4$, and $3.5 \mathrm{~km}$, respectively (Fig. 11).

\section{Discussion}

Evaluating uncertainties in basin and petroleum system models is especially important for complex areas such as the Jebel Akhdar, where sedimentary rocks reached high temperatures and maturities due to deep and rapid burial. In the following, we discuss these uncertainties with respect to temperature and burial history, overpressure buildup, and induced fluid flow. For all presented basin models of the study area, the following assumptions apply: (1) decompacting the present-day lithologies does not consider rock volume lost by pressure solution. This is probably of minor importance in our study area as host-rock-buffered isotope ratios of the veins were interpreted as local sinks for nearby dissolved calcite (Arndt et al., 2014; Hilgers et al., 2006), so the overall rock volume remains approximately constant. (2) Decompaction only accounts for burial, whereas a possible tectonic compaction is neglected (Neumaier, 2015). (3) Calculated overpressure does not include a rock volume decrease due to pressure solution.

\subsection{Burial history}

Little is known about the very early phase of burial before $91 \mathrm{Ma}$ (Figs. 6 and 7; Grobe et al., 2018). The assumptions for this period are based on hypotheses on the tectonic evolution of the passive continental margin as well as data on the thickness of sedimentary units but are not strongly constrained by geological data.

In Turonian times (Robertson, 1987) a southwestwardmoving forebulge, related to plate convergence, affected northern Oman. It eroded the northeastern platform edge and migrated southwestward to the present-day position of the Adam Foothills (Robertson, 1987). Measured thermal maturities of $1.1 \% \mathrm{VR}_{\mathrm{r}}$ were used to reconstruct peak temperatures during burial in Jebel Qusaybah, Adam Foothills, to ca. $140^{\circ} \mathrm{C}$. Numerical basin modeling results reveal that an additional paleo-overburden of a maximum $4 \mathrm{~km}$ (Natih B, Qusaybah, Fig. 10) is required to reach these temperatures. 


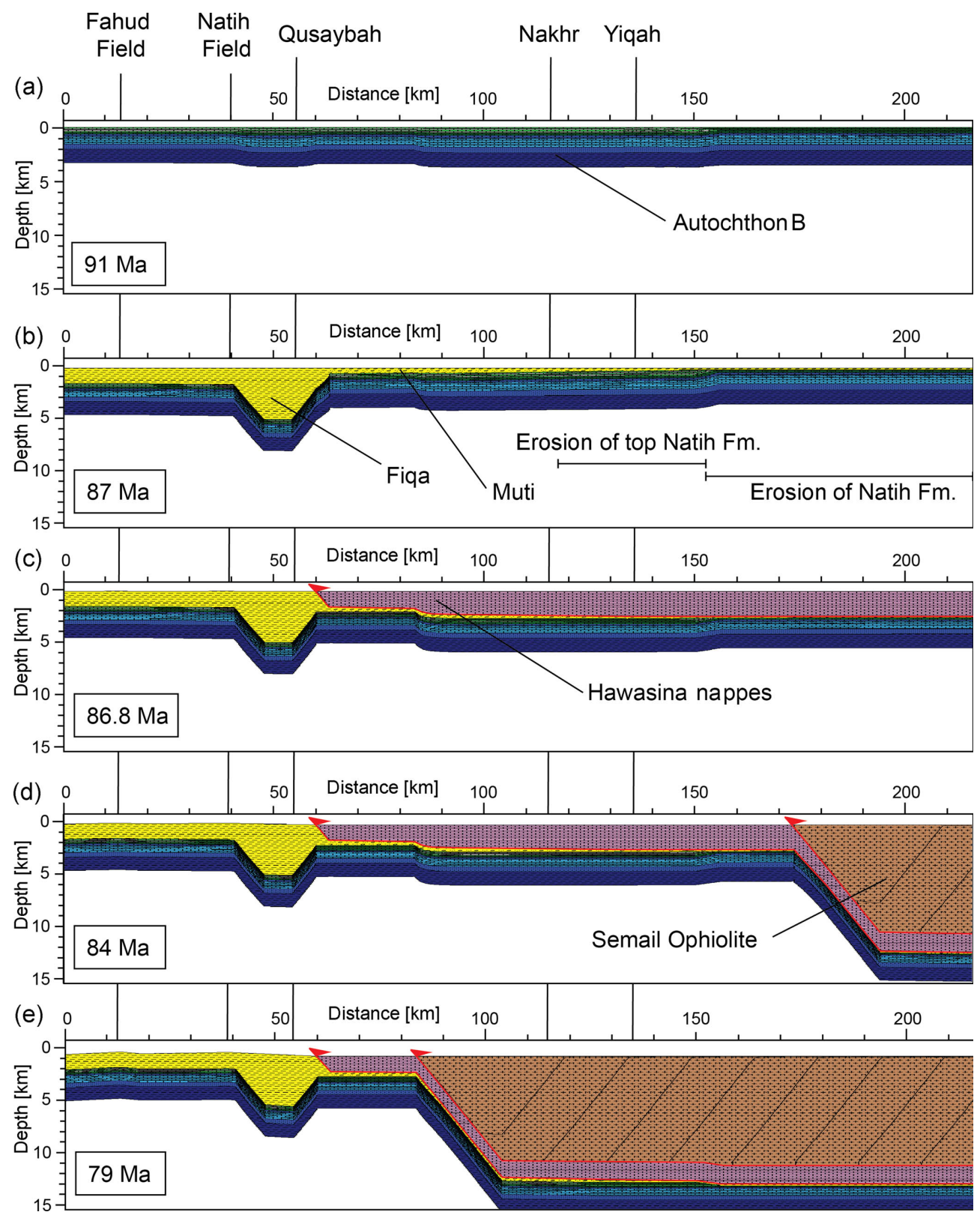

Figure 6. Modeling results: transect evolution from sedimentation of the Autochthon B at stable passive margin conditions (a), moving foredeep that finally filled with Fiqa sediments (b, peak burial as calibrated by thermal maturity data), Hawasina nappe (c), and ophiolite emplacement (d) leading to deepest burial (e). Highlighted with vertical lines in the background are the locations of present-day oil fields and sampled valley locations. Please note the unrealistically flat topography, which is a result of the modeling setup.

The exhumation history of the Adam Foothills is not well known; our model is based on an interpreted late exhumation during the Miocene (Claringbould et al., 2013). Earlier exhumation would shorten the time span of the rock at higher temperatures (Fig. 7), leading to decreased thermal maturity and hence requiring an additional overburden to match the measured thermal maturity data. Therefore, the resulting burial of 4 to $4.5 \mathrm{~km}$ has to be regarded as a minimum value. South of the Adam Foothills basin geometries do not show tilting and are interpreted as not affected by the moving foredeep. Here peak burial was reached under ca. $3 \mathrm{~km}$ of the Fiqa, Hadhramaut, and Fars formations. This is based on the assumption that present-day burial equals deepest burial as no thermal calibration data for the area south of Jebel Qusaybah are available, which is in agreement with the interpretations of Terken (1999) and Warburton et al. (1990).

In the case of the Jebel Akhdar, peak temperatures were reached as a consequence of burial below the ophiolite 


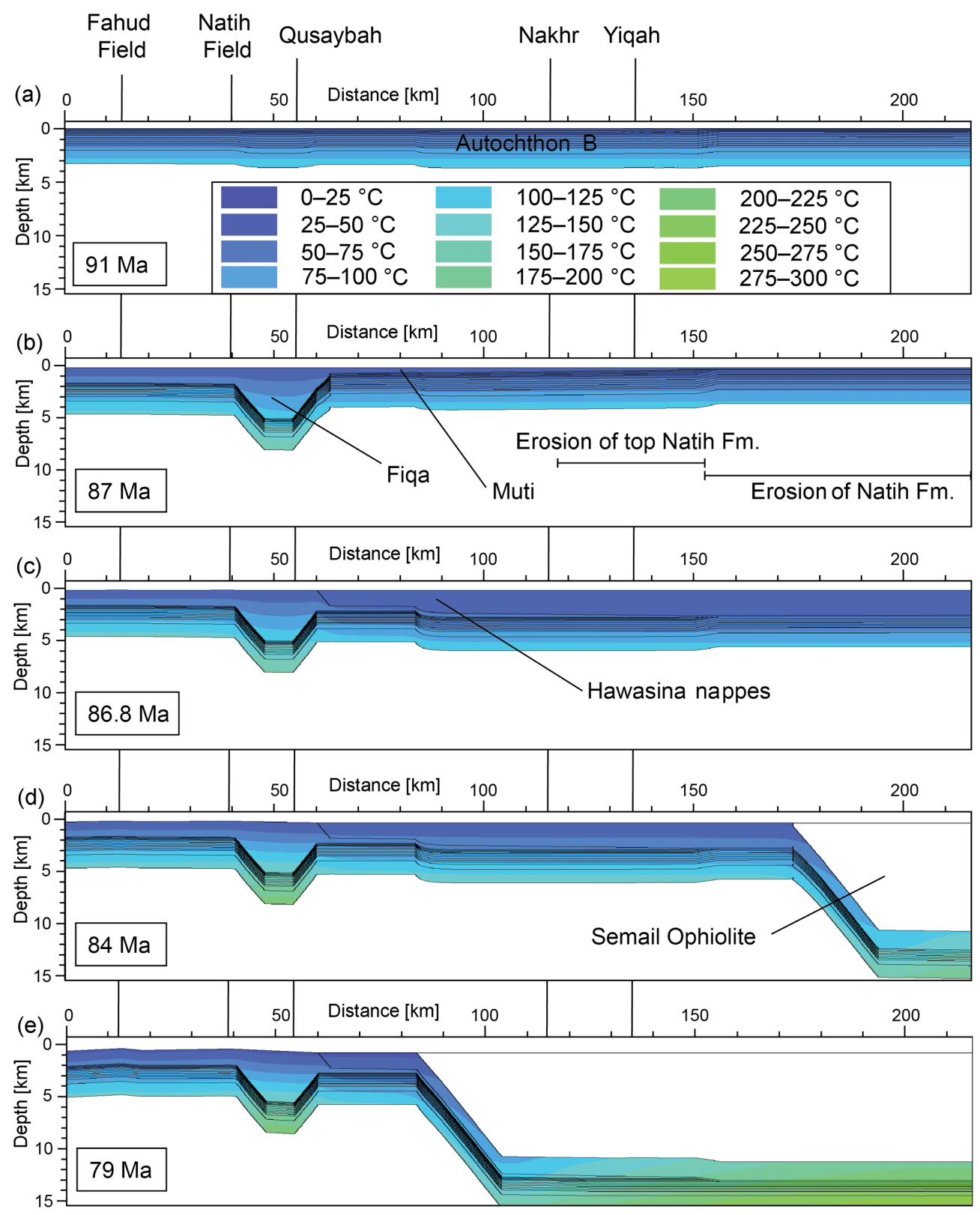

Figure 7. Modeling results: temperature distribution and temporal evolution along the transect of Fig. 6. Highlighted with vertical lines in the background are the locations of present-day oil fields and sampled valley locations.

(Loosveld et al., 1996; Searle et al., 2003; Searle, 2007; Warren et al., 2005). Here the sedimentary rocks reached high temperatures and maturities as shown by solid bitumen reflectance, RSCM, FT-IR, and Rock-Eval pyrolysis data (Fink et al., 2015; Grobe et al., 2016). Pre-obduction burial by sedimentation is not sufficient for such high thermal maturities, and it likewise cannot be explained by increased basal heat flow before $91 \mathrm{Ma}$ or after $55 \mathrm{Ma}$. The influence of local hydrothermal effects cannot be excluded, but because the entire Jebel Akhdar reached high temperatures, short-term local events are unlikely to have been dominant. A regional thermal overprint on the passive margin sediments by warm ophiolite obduction can be excluded and is hence not accounted for in the model. Due to the at least $2 \mathrm{~km}$ thick imbricated Hawasina nappes between the ophiolite and the passive margin sequence, the thermal overprint did not affect the top of the carbonate platform. Limited thermal overprinting of the units underlying the ophiolite is supported by the fact that the sediments of the nappes directly below the ophiolite do not show signs of regional metamorphism in the Jebel Akhdar region (Searle, 1985). Moreover, the thermal imprint as observed by the metamorphic sole in northern 

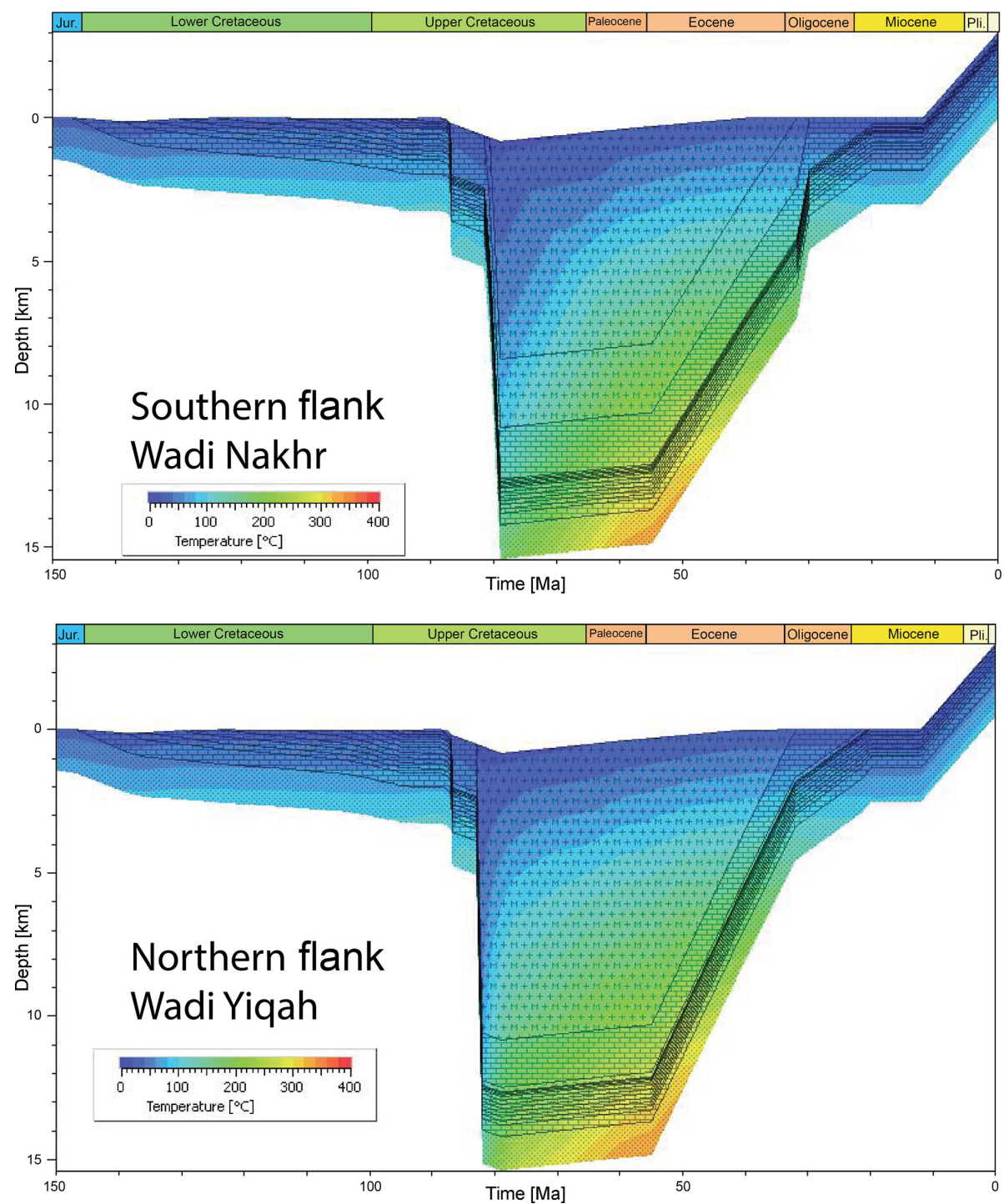

Figure 8. Modeling results: two representative burial plots for two pseudo-wells created near the entrances of Wadi Nakhr and Yiqah (Figs. 1, 6, and 7) show two phases of rapid burial related to Hawasina and Semail nappe emplacement at ca. 88 Ma and ophiolite emplacement at ca. $78 \mathrm{Ma}$. Burial in the north (Wadi Yiqah) starts ca. 2 Myr earlier due to ophiolite obduction taking place from $\mathrm{N}$ to S.

Oman only affects tens of meters in the sub-thrust Hawasina nappes (Searle and Cox, 2002) and not the carbonate platform sediments below. This minor overprint is also observed in other areas (e.g., Wygrala, 1989).

To reach the measured maturity values in the Jebel Akhdar, a paleothickness of the ophiolite of the order of $8-10 \mathrm{~km}$ on top of $2 \mathrm{~km}$ of Hawasina nappes is required (Fig. 10); this corresponds to 280 to $340 \mathrm{MPa}$ of lithostatic pressure, in rough agreement with the pressure reconstructed by combining fluid-inclusion data and independently determined thermal rock maturity temperatures (cf. FI results: $254 \pm$ $30 \mathrm{MPa}$ ).

Basin modeling indicates that highest temperatures were reached later than deepest burial under the ophiolite (Fig. 7), directly prior to exhumation. This difference is interpreted as the time advection needs to heat the rock. Deep burial under the ophiolite represents the only time in the basin's evolution when ductile limestone deformation was possible (Grobe et al., 2018). However, there is uncertainty concerning the exact timing of deepest burial in the Jebel Akhdar (we used $79 \mathrm{Ma}$ according to U-Pb dating of eclogites in the Saih Hatat window; Warren et al., 2005), the related basal heat flow (Discussion section, Fig. S2), and the beginning of early exhumation (we used $55 \mathrm{Ma}$, as discussed below). A later exhumation would not be sufficient to match observed thermal maturities with thermometry data. The slightly higher temperatures of the model compared to thermometry data suggest that an even quicker exhumation might have taken place. 
(a) Temperature evolution: foredeep / Jebel Qusaybah

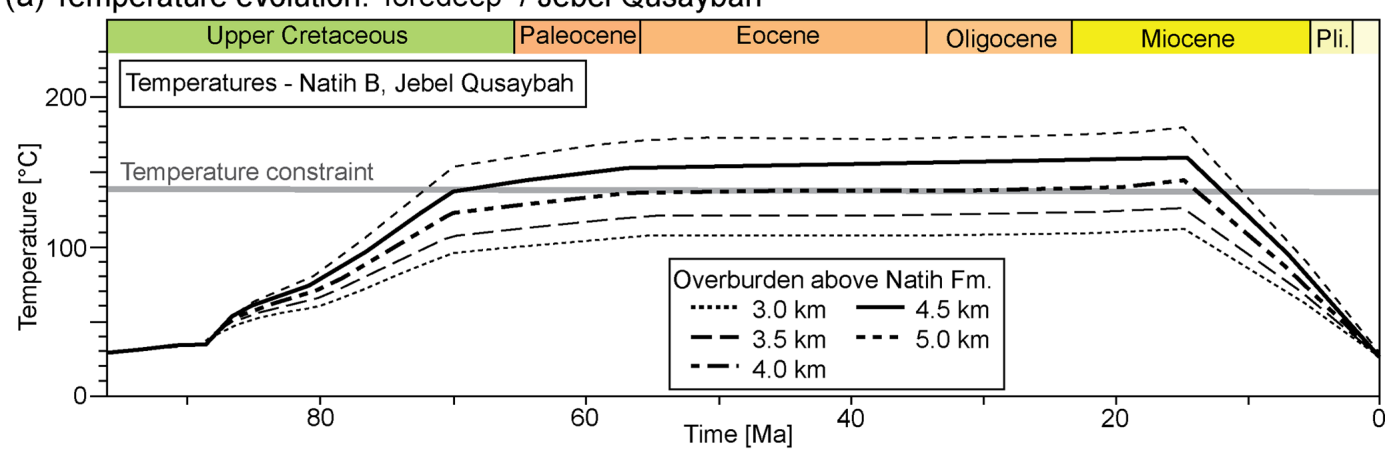

(b) Temperature evolution: S flank / Wadi Nakhr

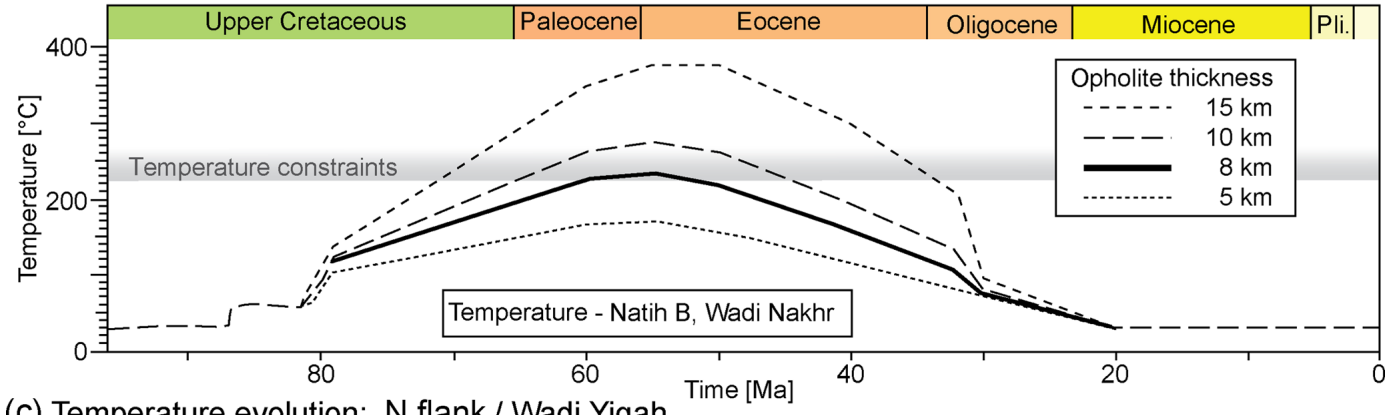

(c) Temperature evolution: $\mathrm{N}$ flank / Wadi Yiqah

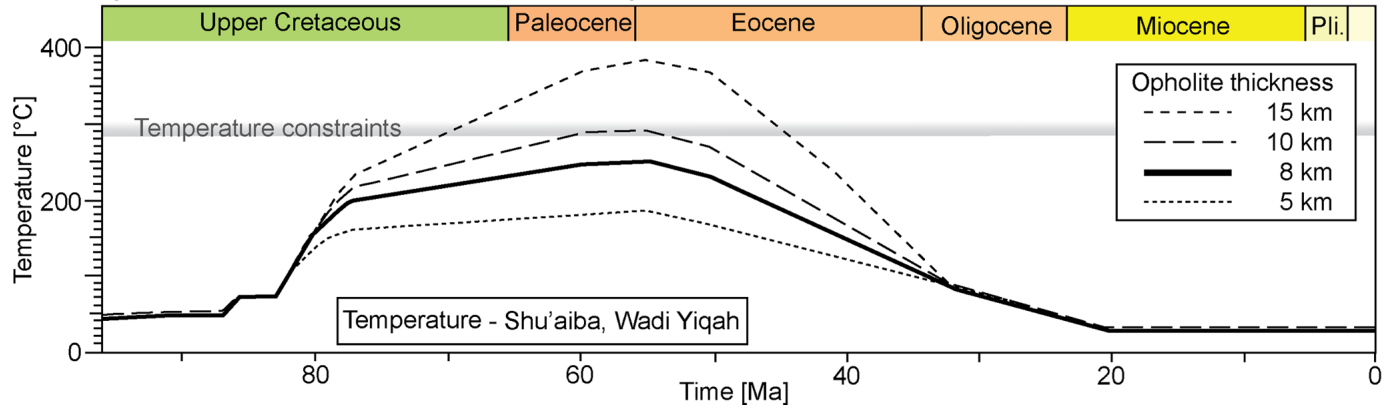

Figure 9. Sensitivity analysis of paleo-overburden and its influences on temperature in comparison to calculated peak temperatures (gray area) for pseudo-wells at Jebel Qusaybah (a), Wadi Nakhr (b), and Wadi Yiqah (c).

Our peak temperatures are in agreement with temperatures of ca. $200^{\circ} \mathrm{C}$ suggested for the top of the carbonate platform by Breton et al. (2004), non-reset zircon fission tracks in the pre-Permian basement indicating peak temperatures up to $280^{\circ} \mathrm{C}$ (Saddiqi et al., 2006), and ductile limestone conditions observed at the Jurassic-Cretaceous boundary (Grobe et al., 2018, Fig. 7). Moreover, thermal maturities in the same stratigraphic units show similar values along the transect and around the dome (Grobe et al., 2016). Hence, we assume a similar burial history for the entire Jebel Akhdar and were able to refine previous models (Grobe et al., 2016) with the larger dataset presented here. The temperatures used in our models are in contrast with recent results on mixed layers of illite-smectite and clay mineral assemblages from the Jebel Akhdar by Aldega et al. (2017), who argue for peak temperatures of $150-200^{\circ} \mathrm{C}$ on the northern flank of the Jebel Akhdar and $120-150^{\circ} \mathrm{C}$ on the southern flank. These values are incompatible with our solid bitumen and Raman spectroscopy data, as well as with the overmature Natih B source rock on the southern flank (data presented here and in Grobe et al., 2016). Independent data on temperatures from fluid inclusions confirm the higher temperature range. At present, there is no clear explanation for this discrepancy. However, it has been shown that the vitrinite reflectance system is more sensitive to rapid temperature changes than clay mineralogy (e.g., Hillier et al., 1995; Velde and Lanson, 1993). If burial was short enough, the clay minerals may not have time to recrystallize, possibly due to a lack of potassium, whereas vitrinite reflectance increases. Alternatively, we speculate that the clay minerals were transformed during top-to-NNE shearing, and thus their state does not show peak burial. Indeed, it has been shown that deformation associated with this early extension reaches deeply into the passive margin sequence and includes the Rayda and Shu'aiba formations (Grobe et 
(a) Maturity calibration: foredeep / Jebel Qusaybah

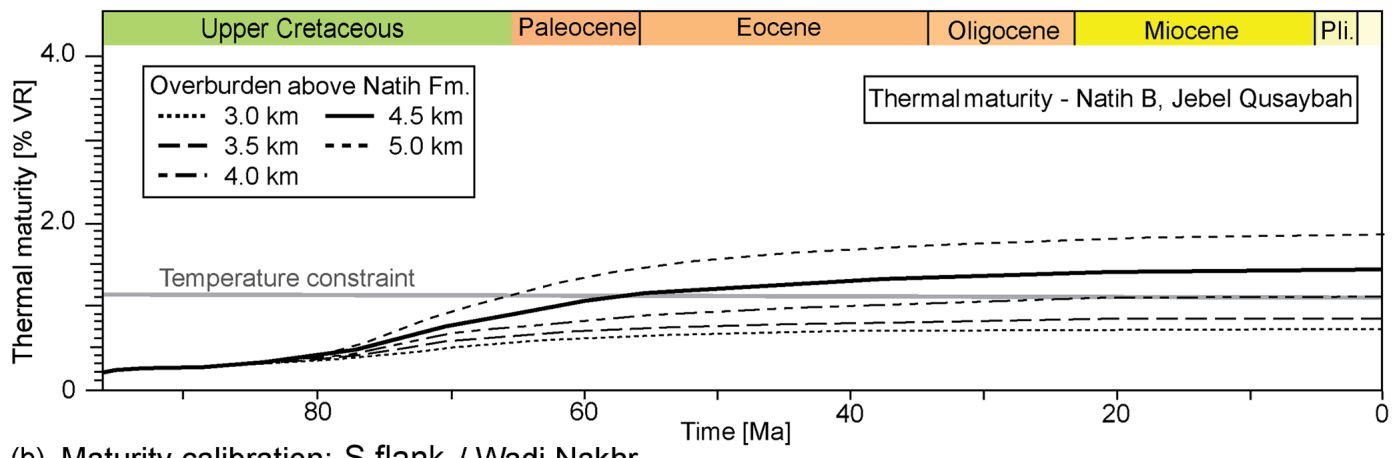

(b) Maturity calibration: S flank / Wadi Nakhr

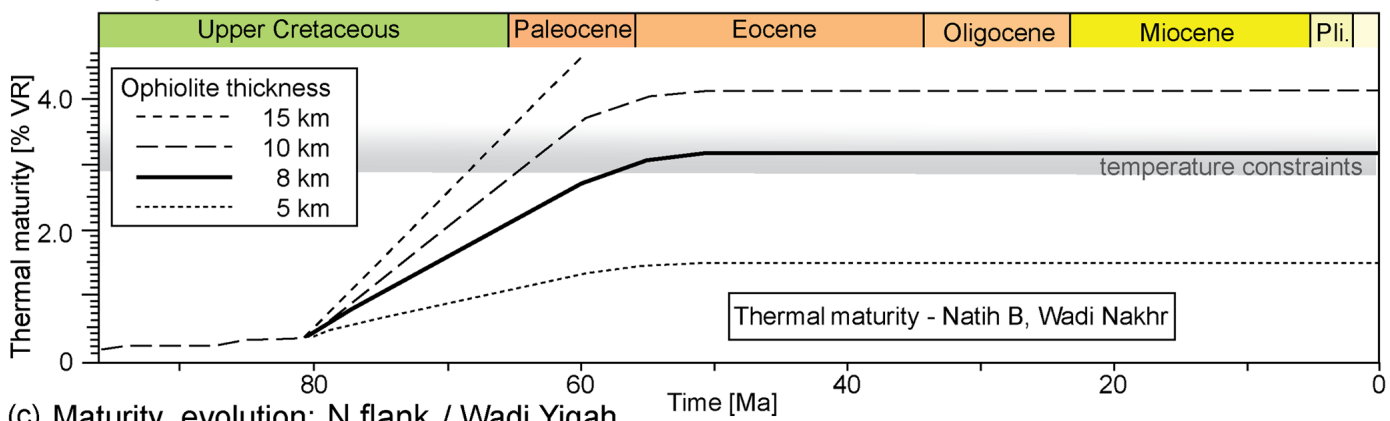

(c) Maturity evolution: $\mathrm{N}$ flank / Wadi Yiqah Time [Ma]

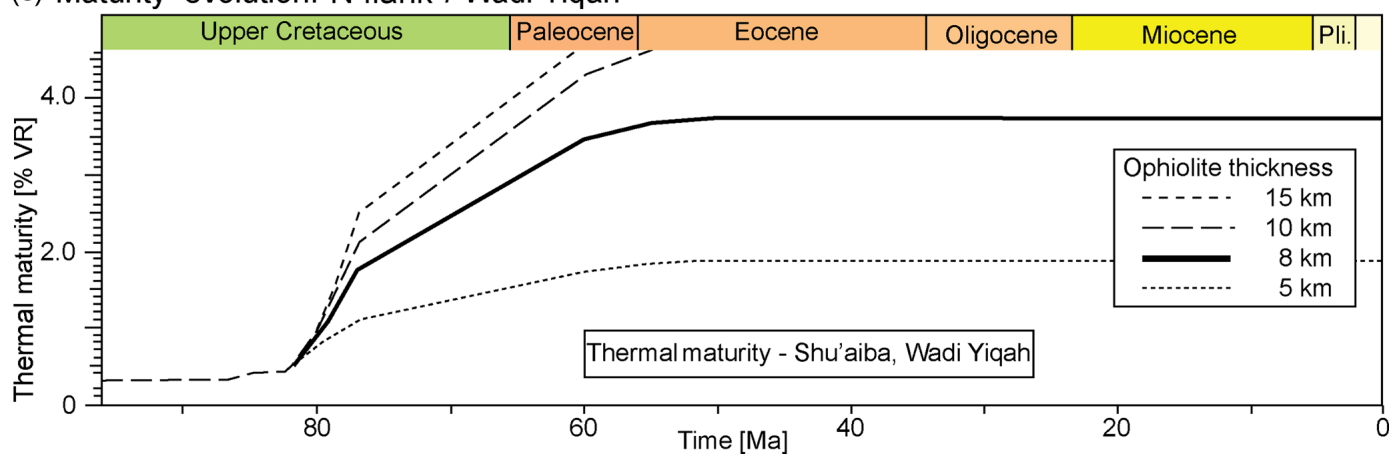

Figure 10. Sensitivity analysis of paleo-overburden and its influences on thermal maturity in comparison to calibration data (gray area). Data are used to calibrate burial depth of the foredeep at the Jebel Qusaybah (a) and the paleo-ophiolite thickness at the southern flank of the mountains at Nakhr (b). Its northern counterpart at Yiqah (c) is in agreement with the temperature data in Fig. 9, but too mature to be reconstructed by standard maturity modeling (Sweeney and Burnham, 1990).

al., 2018; Mattern and Scharf, 2018). Furthermore, Aldega et al. (2017) argue that the cooling history proposed by Grobe et al. (2016) indicates a temperature in the basement $<70{ }^{\circ} \mathrm{C}$ during the Eocene-Oligocene, thus not accounting for thermochronological data in pre-Permian basement rocks. In fact, the calibration data we used for the basement indicate rapid cooling at $55 \pm 5 \mathrm{Ma}$ (Poupeau et al., 1998; Saddiqi et al., 2006), in agreement with models of Grobe et al. (2016) and the exhumation presented in this work.

This exhumation might be a result of the ductile top-toNNE shearing event (64 $\pm 4 \mathrm{Ma}$; Hansman et al., 2018; Grobe et al., 2018). Its onset marks the exhumation of the carbonate platform after deepest burial. Related peak temperatures measured in the fluid inclusions of bedding-parallel veins were estimated to $186-221^{\circ} \mathrm{C}$ by Holland et al. (2009b) as- suming an ophiolitic overburden of 5 km (Sahtan Fm., Wadi Nakhr). If we adjust this pressure correction for higher values of 280 to $340 \mathrm{MPa}$, accounting for the 8 to $10 \mathrm{~km}$ of ophiolite and $2 \mathrm{~km}$ of sedimentary nappes elaborated here, trapping temperatures would increase to ca. $296-364{ }^{\circ} \mathrm{C}$ ( Table 3 ), which are of the order of the maximum burial temperatures as deduced from organic matter maturity.

Figure 12 presents a summary burial graph integrating all presented data in a plot of the temperature evolution over time. Additional pressure data are obtained by fluid-inclusion thermometry: these data indicate paleo-fluid temperatures in the range of $225 \pm 4{ }^{\circ} \mathrm{C}(280 \mathrm{MPa})$ to $266 \pm 5^{\circ} \mathrm{C}(340 \mathrm{MPa})$ during burial under the ophiolite (bedding-confined veins), ca. $296-364^{\circ} \mathrm{C}$ at peak burial (top-to-NNE sheared veins), and $213 \pm 3{ }^{\circ} \mathrm{C}$ during exhumation with a later phase of pri- 
Sensitivity analysis: degree of serpentinization
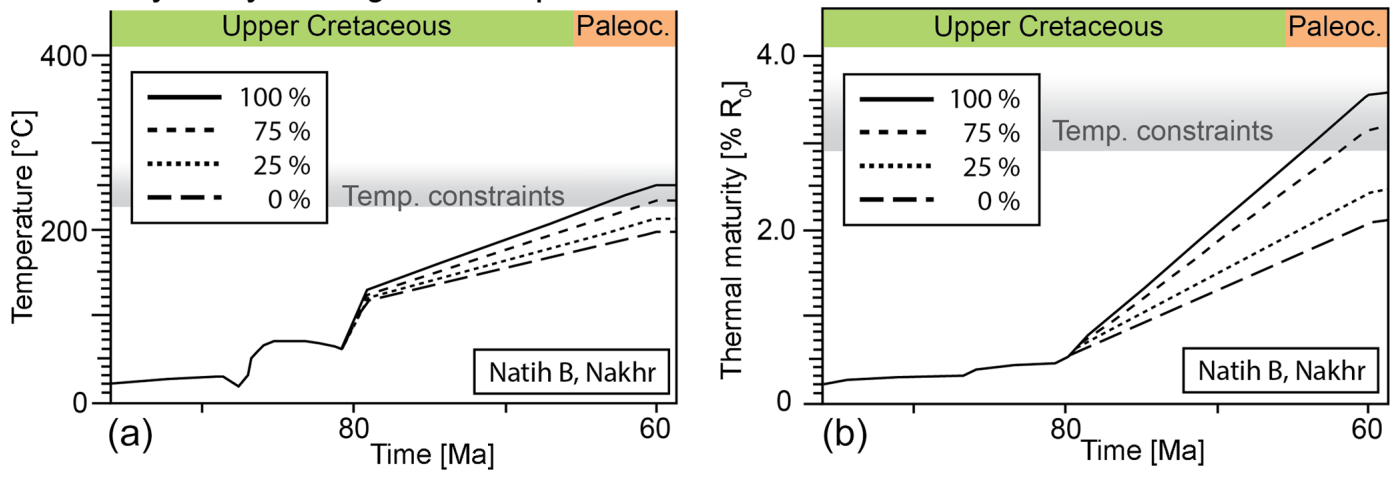

Sensitivity analysis: heat flow variation at peak burial
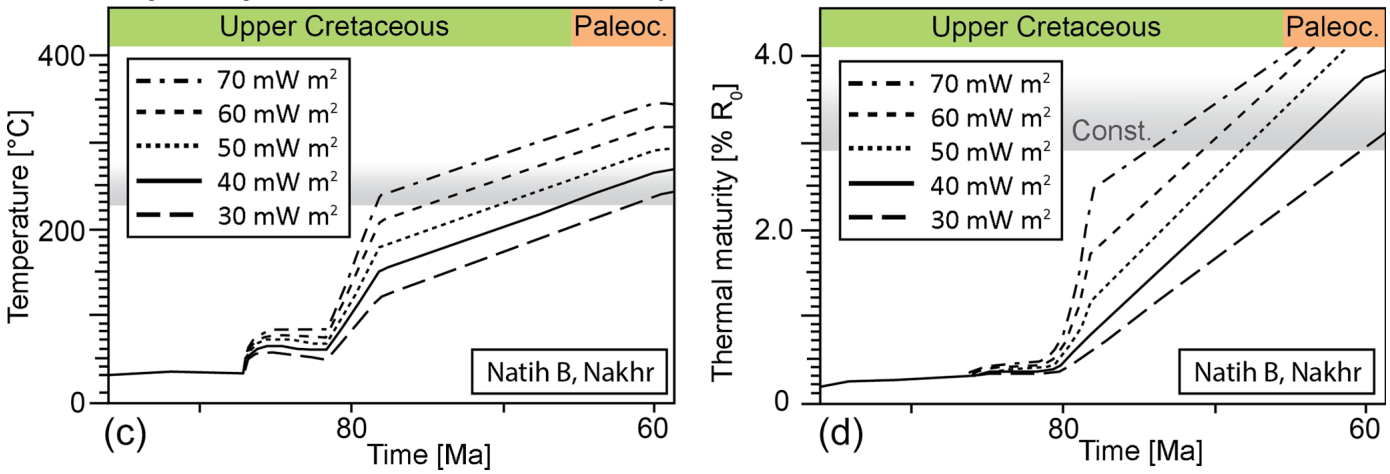

Figure 11. Sensitivity analysis: $(\mathbf{a}, \mathbf{b})$ different degrees of serpentinization of the peridotite within the Semail Ophiolite affect the temperature (a) and thermal maturity (b) evolution (modeled for Natih B Fm. at Wadi Nakhr). Pure peridotite $(0 \%$ serpentinization) requires an additional $3 \mathrm{~km}$ of ophiolite in addition to the $8-10 \mathrm{~km}$ of the best-fit model to equally match the calibration data; $100 \%$ refers to complete serpentinization of the peridotite in the ophiolite. (c, d) The influence of variable heat flow values at peak burial on temperature (a) and thermal maturity (b).

mary inclusion outlining $184 \pm 3$ to $189 \pm 7^{\circ} \mathrm{C}$ (both strikeslip-related veins). Temperature decrease within the latterformed parts of the strike-slip veins might relate to a change in fluid source or to exhumation during vein formation. In combination with our thermochronology data the second possibility appears more likely and would imply that strikeslip faults developed after ca. $55 \mathrm{Ma}$.

\subsection{Exhumation history}

Our new thermochronology data from the central part of the Jebel Akhdar Dome suggest cooling below the reset temperature of the $\mathrm{ZHe}$ thermochronometer (ca. $130-170^{\circ} \mathrm{C}$ ) between $48.7 \pm 1.8$ and $39.8 \pm 3.0 \mathrm{Ma}$ (Table 2, Fig. 4). The small variation in cooling ages for the different stratigraphic levels indicates rapid passage of the entire rock suite through the ZHe partial retention zone and consequently rapid exhumation of the Jebel Akhdar Dome. This Eocene cooling is in agreement with $\mathrm{ZHe}$ ages of pre-Permian strata from Hansman et al. (2017) ranging between $62 \pm 3$ and $39 \pm 2 \mathrm{Ma}$. Apatite fission track (AFT) ages measured in the basement of the Jebel Akhdar range between $55 \pm 5$ and $48 \pm 7 \mathrm{Ma}$ (four samples; Poupeau et al., 1998) and between $51 \pm 8$ and
$32 \pm 4 \mathrm{Ma}$ (Hansman et al., 2017). The temperature of resetting the AFT system (i.e., the depth of the base of the partial annealing zone) may vary depending on annealing kinetics. For different apatite crystals this temperature ranges between 100 and $120^{\circ} \mathrm{C}$ (Carlson et al., 1999; Fitzgerald et al., 2006). Hence, these AFT ages reproduce within error with our $\mathrm{ZHe}$ results, despite the fact that both systems are sensitive to different temperature intervals $\left(100-120\right.$ and $130-170^{\circ} \mathrm{C}$, respectively). This supports the interpretation of rapid exhumation of the Jebel Akhdar at ca. $55 \mathrm{Ma}$. Zircon fission track ages witness cooling of the Jebel Akhdar below ca. $260^{\circ} \mathrm{C}$ between 96 and $70 \mathrm{Ma}$ (Saddiqi et al., 2006). This implies slow cooling thereafter (ca. $100^{\circ}$ between 70 and $55 \mathrm{Ma}$ ) until rapid exhumation at ca. $55 \mathrm{Ma}$. Earlier exhumation would not result in the required thermal maturities as the exposure of the rock to highest temperatures would be too short for thermal equilibration. A reheating event in the late Miocene is not required to explain the data.

Our ZHe data from the Muti Formation and the Hawasina nappes show a spread in ages between 173 and $43 \mathrm{Ma}$, i.e., partly much older than the ages observed in the stratigraphically lower units in the center of the dome. 


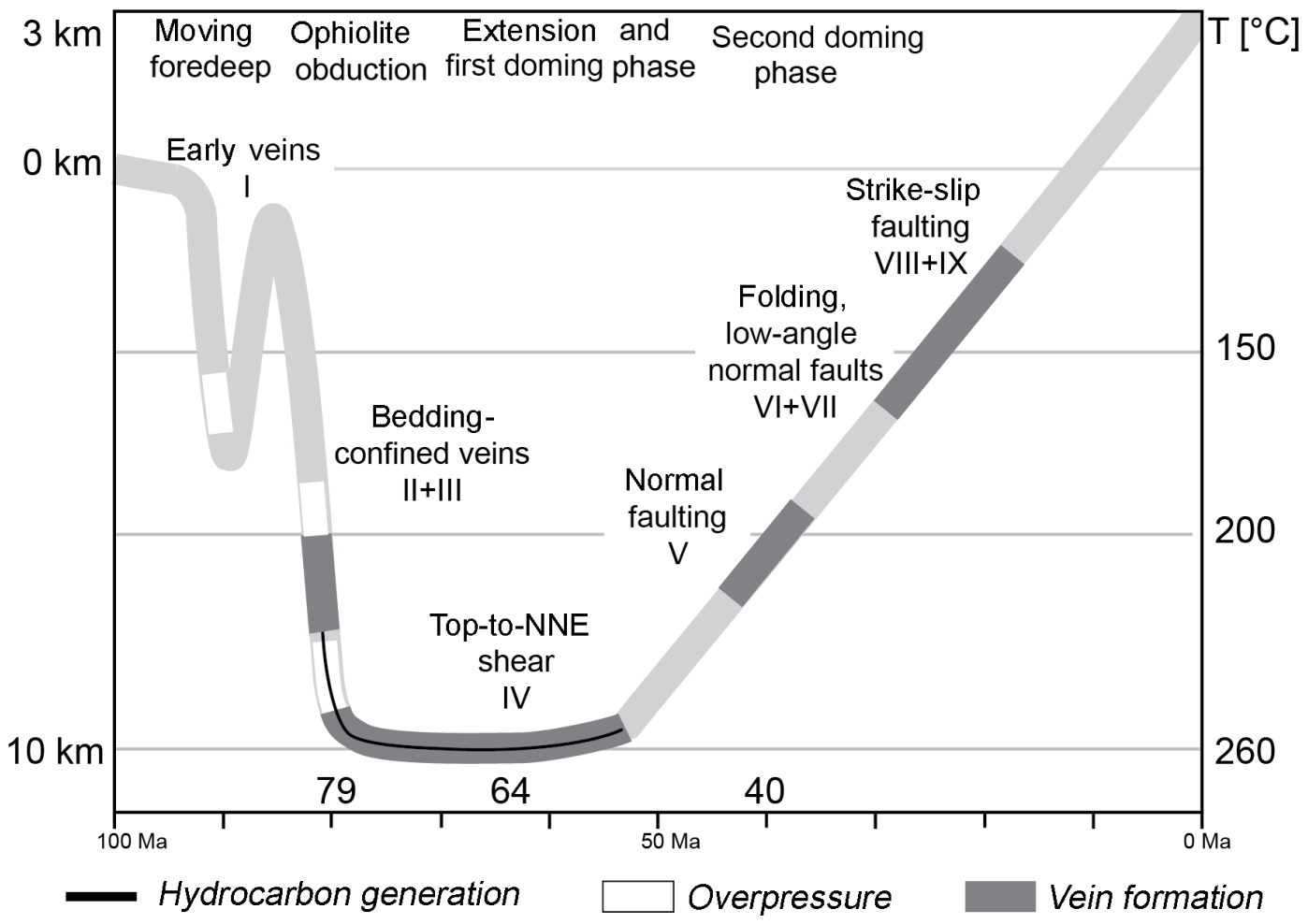

Figure 12. Summary sketch of burial and exhumation for the top of the carbonate platform (Natih Fm.) integrating all presented datasets. Headings refer to the tectonic phases and captions to the structural generations I-IX (Grobe et al., 2018); enlarged ages reflect deepest burial reached at ca. $79 \mathrm{Ma}$, the onset of initial dome formation at $64 \mathrm{Ma}$ (top-to-NNE shearing), and rapid exhumation active at $40 \mathrm{Ma}$. Temperatures on the right are based on RSCM and FI thermometry. Pressure at peak burial is calculated from FI measurements and independently determined temperature data to $p_{\mathrm{p}}=254 \pm 30 \mathrm{MPa}$ and $p_{\mathrm{L}}=340 \mathrm{MPa}$. The exhumation history is reconstructed from $\mathrm{ZHe}$ ages

A spread in $(\mathrm{U}-\mathrm{Th}) / \mathrm{He}$ ages is often observed and has been attributed to radiation damage density, uneven distribution of mother isotopes in the dated crystal, broken grains, and grain chemistry, among other causes (e.g., Flowers et al., 2009; Guenther et al., 2013). Several studies show that samples from sedimentary rocks are particularly prone to spread in ages (e.g., von Hagke et al., 2012; Ketcham et al., 2018; Levina et al., 2014). This is because transported grains are subject to abrasion, which influences age correction for grain geometry and may obscure the presence of inclusions within the crystal. Additionally, dated grains can originate from different sources and thus have a different chemical composition and a different pre-depositional temperature history. This may result in different reset temperatures, and consequently different grains (or grain age populations) represent different thermochronometers.

It is difficult to prove the existence of such multiple thermochronometers, as independent parameters indicative for different kinetics have not yet been established. Indeed, statistical analysis of different grain age populations requires dating of multiple grains (e.g., to be $95 \%$ certain that a population representing $5 \%$ of the grains is not missed, 117 single grain ages need to be dated; Vermeesch, 2004). In any case, reproducing ages determined in different samples indi- cates that the data are geologically meaningful; i.e., the observed spread is the result of partial resetting and/or different kinetics and not the result of factors independent of the timetemperature history, such as undetected inclusions or external helium implantation. We thus interpret the system as only partially reset, implying these units were not heated above the reset temperature (approximately $130-170{ }^{\circ} \mathrm{C}$ ) after deposition. This interpretation is corroborated by unreset $\mathrm{ZHe}$ ages in the Hawasina window (Fig. 1; László Csontos, personal communication, 2014). The top of the Natih Formation experienced temperatures above $220^{\circ} \mathrm{C}$. We suggest that this apparent contradiction may be explained by juxtaposition of the colder Muti and Hawasina units against the top of the carbonate platform during extensional top-to-NNE shearing. This implies that at least $50^{\circ} \mathrm{C}$ of the cooling is associated with post-obduction extension, i.e., before doming. A twostage exhumation history of the Jebel Akhdar Dome has also been inferred from structural data (Grobe et al., 2018; Mattern and Scharf, 2018) and the stratigraphic record (Fournier et al., 2006; Mann et al., 1990). Top-to-NNE shearing is associated with tectonic thinning of the ophiolite (Grobe et al., 2018). This tectonic denudation will also result in cooling and may explain why so little ophiolite is found in the post- 
obduction sediments. Additionally, ophiolitic material may have been lost to the Gulf of Oman.

\subsection{Pressure evolution}

Evolution of pore pressures was modeled (Figs. S7 and S8) assuming a seal on top of the Natih Fm. $\left(k_{\text {Muti }}=10^{-23} \mathrm{~m}^{2}\right)$. Porosity was lost during Muti deposition in the moving forebulge (top seal) and related burial and the emplacement of the Hawasina nappes and the ophiolite, which induced compaction and a remaining very low porosity of ca. $1 \%$. Hydrostatic pressure increased with burial under the moving forebulge at $88 \mathrm{Ma}$ to $40 \mathrm{MPa}$, after Muti deposition to $60 \mathrm{MPa}$ and after ophiolite emplacement to $120 \mathrm{MPa}$. There is a calculated pore pressure rise above hydrostatic pressure in response to Hawasina nappe and ophiolite emplacement.

The formation of tensile fractures, as inferred from bedding-confined mode I veins in the Natih Fm. (Arndt et al., 2014; Grobe et al., 2018; Holland et al., 2009b; Virgo, 2015), requires internal fluid pressures $\left(P_{\mathrm{f}}\right)$ exceeding the sum of the stress acting normal on the fracture surface $\left(\sigma_{3}\right)$ and the tensile stress of the rock $(T): P_{\mathrm{f}}>\sigma_{3}+T$ and a differential stress $\left(\sigma_{1}-\sigma_{3}\right)$ below $4 T$ (Secor Jr., 1965). Host-rock-buffered vein isotope compositions indicate that the veins were formed by local fluids (Arndt et al., 2014) and hence require local overpressure cells.

Sensitivity analyses of reduced permeabilities of the Muti, Natih, and Nahr Umr formations show that the overpressure generation necessary for rock fracturing requires a very good top seal and also a reduced horizontal permeability of the Natih Fm. of $10^{-23} \mathrm{~m}^{2}$ (Figs. S7 and S8). A top seal on its own is not sufficient for overpressure to initiate rock failure. This case results in pore pressures up to $300 \mathrm{MPa}$ within the top Natih and localized overpressures of $195 \mathrm{MPa}$ in front of the obducting ophiolite.

All results indicate that without low horizontal permeabilities of the Natih Fm. $\leq 10^{-23} \mathrm{~m}^{2}$ the overpressure cells required for vein formation cannot be generated. The reduced permeabilities in the Natih Fm. are necessary to prevent an early, tectonically driven horizontal pressure release.

\subsection{Fluid migration}

Numerical basin modeling shows that rapid burial of sedimentary rocks below the ophiolite (88-80 Ma) caused undercompaction, i.e., a porosity too high with respect to burial depth, and consequent pore pressure increase. Two example model results of fluid migration in front of the obducting ophiolite are shown in the Supplement Fig. S9. If low permeabilities are assigned to the non-source-rock members of the Natih Fm., migration will mainly take place within the source rocks and at layer interfaces within the Natih Fm. If the complete Natih Fm. has low permeabilities, fluids will leave the source rock vertically first before lateral migration localizes along layer boundaries. The pressure gradient between overpressures below the allochthonous nappes and the less deeply buried southern foreland initiates tectonically driven fluid migration in front of the obducting nappes, an idea that was first introduced by Oliver (1986). Solid bitumen accumulations in black-stained calcite veins are in agreement with this interpretation (Fink et al., 2015).

Dome formation of the Jebel Akhdar anticline around $55 \mathrm{Ma}$ initiated layer tilting and consequent northward migration of the generated hydrocarbons as observed by secondary low-reflective solid bitumen generations in Natih veins and host rocks at the southern flank of the Oman mountains (Fink et al., 2015; Grobe et al., 2016).

\section{Conclusions}

This study provides insights into temperature evolution during obduction and prior to subsequent orogenesis.

Arabia's passive continental margin was buried to at least $4 \mathrm{~km}$ at times of foredeep migration and afterwards under $8-10 \mathrm{~km}$ of Semail Ophiolite and $2 \mathrm{~km}$ of sedimentary Hawasina nappes. Deepest burial under the ophiolite resulted in peak temperatures of up to $300^{\circ} \mathrm{C}$ (Shu'aiba Fm.) with sub-lithostatic pore pressures. Ophiolite obduction and overpressure cells expelled fluids towards the foreland through matrix and fracture porosity.

$\mathrm{ZHe}$ data show cooling associated with forebulge migration, as well as with exhumation of the Jebel Akhdar Dome.

Exhumation of the Jebel Akhdar Dome took place in two stages. A first stage is associated with top-to-NNE shearing, which is responsible for at least $50^{\circ} \mathrm{C}$ of the cooling, as witnessed by the juxtaposition of units including partially reset $\mathrm{ZHe}$ ages against units that experienced more than $220^{\circ} \mathrm{C}$. ZHe data show that the second exhumation phase, associated with doming of the Jebel Akhdar, occurred between 49 and $39 \mathrm{Ma}$.

Data availability. All generated laboratory data are shown in this paper and the provided Supplement.

Supplement. The supplement related to this article is available online at: https://doi.org/10.5194/se-10-149-2019-supplement.

Author contributions. JLU, RL, and AG initiated and planned the study. AG planned and carried out fieldwork as well as thermal maturity measurements (VR, solid bitumen reflectance, Raman spectroscopy), structural interpretations, and basin modeling. $\mathrm{AG}, \mathrm{CvH}$, JLU, ID, and FW carried out fieldwork and structural interpretations. FW and ID conducted the thermochronological measurements with the help of $\mathrm{CvH}$. PM and $\mathrm{AG}$ performed fluid-inclusion thermometry.

$\mathrm{AG}$ and $\mathrm{CvH}$ prepared the paper with contributions from all coauthors. 
Competing interests. The authors declare that they have no conflict of interest.

Acknowledgements. We acknowledge the highly appreciated help of Donka Macherey (sample preparation, RWTH Aachen), the team of the KU Leuven (fluid-inclusion measurements), and Keno Lünsdorf (Raman spectroscopy, Georg-August University, Göttingen). Sample crushing was realized by the team of SELFRAG, Switzerland. Wiekert Visser and Victoria Sachse are thanked for fruitful discussions; Gösta Hoffmann and Wilfried Bauer of GUtech are thanked for helping with field logistics. We are grateful for comments from Edwin Gnos, Andreas Scharf, WolfChristian Dullo, and Mark Handy on earlier versions of this paper and the reviews of Massimiliano Zattin, Luca Aldega, Bruce Levell, and Federico Rossetti.

Edited by: Federico Rossetti

Reviewed by: Luca Aldega, Massimiliano Zattin, and Bruce Levell

\section{References}

Agard, P., Omrani, J., Jolivet, L., and Mouthereau, F.: Convergence history across Zagros (Iran): constraints from collisional and earlier deformation, Int. J. Earth Sci., 94, 401-419, https://doi.org/10.1007/s00531-005-0481-4, 2005.

Aldega, L., Carminati, E., Scharf, A., Mattern, F., and AlWardi, M.: Estimating original thickness and extent of the Semail Ophiolite in the eastern Oman Mountains by paleothermal indicators, Mar. Pet. Geol., 84, 18-33, https://doi.org/10.1016/j.marpetgeo.2017.03.024, 2017.

Aldega, L., Bigi, S., Carminati, E., Trippetta, F., Corrado, S., and Kavoosi, M. A.: The Zagros fold-and-thrust belt in the Fars province (Iran): II. Thermal evolution, Mar. Pet. Geol., 93, 376-390, https://doi.org/10.1016/J.MARPETGEO.2018.03.022, 2018.

Al Habsi, N., Al Shukaili, M., Al Tooqi, S., Ehrenberg, S. N., and Bernecker, M.: Lithofacies, diagenesis and reservoir quality of Upper Shu'aiba reservoirs in northwestern Oman, GeoArabia, 19, 145-182, 2014.

Al-Lazki, A. I., Seber, D., Sandvol, E., and Barazangi, M.: A crustal transect across the Oman Mountains on the eastern margin of Arabia, GeoArabia, 7, 47-78, 2002.

Al-Wardi, M. and Butler, R. W. H.: Constrictional extensional tectonics in the northern Oman mountains, its role in culmination development and the exhumation of the subducted Arabian continental margin, Geol. Soc. London, Spec. Publ., 272, 187-202, https://doi.org/10.1144/GSL.SP.2007.272.01.11, 2007.

Aoya, M., Kouketsu, Y., Endo, S., Shimizu, H., Mizukami, T., Nakamura, D., and Wallis, S.: Extending the applicability of the Raman carbonaceous-material geothermometer using data from contact metamorphic rocks, J. Metamorph. Geol., 28, 895-914, https://doi.org/10.1111/j.1525-1314.2010.00896.x, 2010.

Arndt, M.: On microstructures, fluid pathways and sealing of fractures in exhumed carbonate reservoir outcrop analogues in the Oman Mountains, PhD thesis, RWTH Aachen University, 2015.

Arndt, M., Virgo, S., Cox, S. F., and Urai, J. L.: Changes in fluid pathways in a calcite vein mesh (Natih Fm, Oman Moun- tains): insights from stable isotopes, Geofluids, 14, 391-418, https://doi.org/10.1111/gfl.12083, 2014.

Barker, C. E. and Goldstein, R. H.: Fluid-inclusion technique for determining maximum temperature in calcite and its comparison to the vitrinite reflectance geothermometer, Geology, 18, 1003 1006, 1990.

Barker, C. E. E. and Pawlewicz, M. J. J.: Calculation of vitrinite reflectance from thermal histories and peak temperatures, in: Vitrinite Reflectance as a Maturity Parameter, edited by: Mukhopadhyay, P. and Dow, W., American Chemical Society, 570, 216 229, 1994.

Béchennec, F., Metour, J. L. E., Rabu, D., Villey, M., and Beurrier, M.: The Hawasina Basin: A fragment of a starved passive continental margin, thrust over the Arabian Platform during obduction of the Sumail Nappe, Tectonophysics, 151, 323-343, https://doi.org/10.1016/0040-1951(88)90251-X, 1988.

Béchennec, F., Le Metour, J., Rabu, D., Bourdillon-de-Grissac, C., de Wever, P., Beurrier, M., and Villey, M.: The Hawasina Nappes: stratigraphy, palaeogeography and structural evolution of a fragment of the south-Tethyan passive continental margin, Geol. Soc. London, Spec. Publ., 49, 213-223, https://doi.org/10.1144/GSL.SP.1992.049.01.14, 1990.

Bernoulli, D., Weissert, H., and Blome, C. D.: Evolution of the Triassic Hawasina Basin, Central Oman Mountains, Geol. Soc. London, Spec. Publ., 49, 189-202, https://doi.org/10.1144/GSL.SP.1992.049.01.12, 1990.

Beurrier, M., Bechennec, F., Rabu, D., and Hutin, G.: Geological Map of Rustaq - explanatory notes, Sultanat Oman, Minist. Pet Miner., 1986.

Beyssac, O., Goffé, B., Chopin, C., and Rouzaud, J. N.: Raman spectra of carbonaceous material in metasediments: A new geothermometer, J. Metamorph. Geol., 20, 859-871, https://doi.org/10.1046/j.1525-1314.2002.00408.x, 2002.

Bodnar, R. J.: Revised equation and table for determining the freezing point depression of $\mathrm{H}_{2} \mathrm{O}-\mathrm{NaCl}$ solutions, Gechim. Cosmochim. Ac., 57, 683-684, 1993.

Breton, J. P., Béchennec, F., Le Métour, J., Moen-Maurel, L., and Razin, P.: Eoalpine (Cretaceous) evolution of the Oman Tethyan continental margin: Insights from a structural field study in Jabal Akhdar (Oman Mountains), GeoArabia, 9, 41-58, 2004.

Brown, P. E.: FLINCOR; a microcomputer program for the reduction and investigation of fluid-inclusion data, Am. Mineral., 74, 1390-1393, 1989.

Carlson, W. D., Donelick, R. A., and Ketcham, R. A.: Variability of apatite fission-track annealing kinetics: I. Experimental results, Am. Mineral., 84, 1213-1223, https://doi.org/10.2138/am-19990901, 1999.

Claringbould, J. S., Hyden, B. B., Sarg, J. F., and Trudgill, B. D.: Structural evolution of a salt-cored, domed, reactivated fault complex, Jebel Madar, Oman, J. Struct. Geol., 51, 118-131, https://doi.org/10.1016/j.jsg.2013.03.001, 2013.

Coleman, R. G.: Tectonic Setting for Ophiolite Obduction in Oman, J. Geophys. Res., 86, 2497-2508, 1981.

Cooper, D. J. W., Ali, M. Y., and Searle, M. P.: Structure of the northern Oman Mountains from the Semail Ophiolite to the Foreland Basin, Geol. Soc. London, Spec. Publ., 392, 129-153, 2014.

Cowan, R. J., Searle, M. P., and Waters, D. J.: Structure of the metamorphic sole to the Oman Ophiolite, Sumeini Window and Wadi Tayyin: implications for ophiolite obduction 
processes, Geol. Soc. London, Spec. Publ., 392, 155-175, https://doi.org/10.1144/SP392.8, 2014.

De Keijzer, M., Hillgartner, H., Al Dhahab, S., and Rawnsley, K.: A surface-subsurface study of reservoir-scale fracture heterogeneities in Cretaceous carbonates, North Oman, Geol. Soc. London, Spec. Publ., 270, 227-244, https://doi.org/10.1144/GSL.SP.2007.270.01.15, 2007.

Deville, E. and Sassi, W.: Contrasting thermal evolution of thrust systems: An analytical and modeling approach in the front of the western Alps, Am. Assoc. Pet. Geol. Bull., 90, 887-907, https://doi.org/10.1306/01090605046, 2006.

Diamond, L. W.: Introduction to gas-bearing, aqueous fluid inclusions, in: Fluid Inclusions: Analysis and Interpretation, edited by: Samson, I. M., Anderson, A., and Marshall, D., 32, chap. 5, 363372, Mineralogical Association of Canada Short Course Series, 2003.

Duretz, T., Agard, P., Yamato, P., Ducassou, C., Burov, E. B., and Gerya, T. V.: Thermo-mechanical modeling of the obduction process based on the Oman Ophiolite case, Gondwana Res., 32, 110, https://doi.org/10.1016/j.gr.2015.02.002, 2015.

Ferreiro Mählmann, R.: Correlation of very low grade data to calibrate a thermal maturity model in a nappe tectonic setting, a case study from the Alps, Tectonophysics, 334, 1-33, 2001.

Filbrandt, J. B., Al-Dhahab, S., Al-Habsy, A., Harris, K., Keating, J., Al-mahruqi, S., Ozkaya, S. I., Richard, P. D., and Robertson, T.: Kinematic interpretation and structural evolution of North Oman, Block 6, since the Late Cretaceous and implications for timing of hydrocarbon migration into Cretaceous reservoirs, GeoArabia, 11, 97-115, 2006.

Fink, R., Virgo, S., Arndt, M., Visser, W., Littke, R., and Urai, J. L. L.: Solid bitumen in calcite veins from the Natih Formation in the Oman Mountains: multiple phases of petroleum migration in a changing stress field, Int. J. Coal Geol., 157, 39-51, https://doi.org/10.1016/j.coal.2015.07.012, 2015.

Fitzgerald, P. G., Baldwin, S. L., Webb, L. E., and O'ullivan, P.: He data from slowly cooled crustal terranes and the interpretation of intra-sample variations of single crystal apatite ages from vertical profiles, Chem. Geol., 225, 91-120, 2006.

Flowers, R. M., Ketcham, R. A., Shuster, D. L., and Farley, K. A.: Apatite (U-Th)/He thermochronometry using a radiation damage accumulation and annealing model, Geochim. Cosmochim. Ac., 73, 2347-2365, https://doi.org/10.1016/J.GCA.2009.01.015, 2009.

Forbes, G. A., Jansen, H. S. M., and Schreurs, J.: Lexicon of Oman - Subsurface Stratigraphy - Reference Guide to the Stratigraphy of Oman's Hydrocarbon Basins, GeoArabia Spec. Publ., 5, 2010.

Fournier, M., Lepvrier, C., Razin, P., and Jolivet, L.: Late Cretaceous to Paleogene post-obduction extension and subsequent Neogene compression in the Oman Mountains, GeoArabia, 11, 17-40, 2006.

Glennie, K. W., Boeuf, M. G. A., Clarke, M. W. H., Moody-Stuart, M., Pilaar, W. F. H., and Reinhardt, B. M.: Late Cretaceous Nappes in Oman Mountains and Their Geologic Evolution: Reply, Am. Assoc. Pet. Geol. Bull., 57, 5-27, 1973.

Glennie, K. W., Boeuf, M. G. A., Hughes Clarke, M. W., MoodyStuart, M., Pilaar, W. F. H., and Reinhardt, B. M.: Geology of the Oman Mountains, Verh. van het K. Ned. Geol. Mijnbouwkd. Genoot., 31, 432 pp., 1974.
Gnos, E. and Peters, T.: K-Ar ages of the metamorphic sole of the Semail Ophiolite: implications for ophiolite cooling history, Contrib. to Mineral. Petrol., 113, 325-332, 1993.

Goldstein, R. H.: Fluid inclusions in sedimentary and diagenetic systems, Lithos, 55, 159-193, https://doi.org/10.1016/S00244937(00)00044-X, 2001.

Gomez-Rivas, E., Bons, P. D., Koehn, D., Urai, J. L., Arndt, M., Virgo, S., Laurich, B., Zeeb, C., Stark, L., and Blum, P.: The Jabal Akhdar Dome in the Oman mountains: Evolution of a dynamic fracture system, Am. J. Sci., 314, 1104-1139, https://doi.org/10.2475/07.2014.02, 2014.

Grelaud, C., Razin, P., Homewood, P. W., and Schwab, A. M.: Development of Incisions on a Periodically Emergent Carbonate Platform (Natih Formation, Late Cretaceous, Oman), J. Sediment. Res., 76, 647-669, https://doi.org/10.2110/jsr.2006.058, 2006.

Grobe, A., Littke, R., Urai, J. L. J. L. L., Lünsdorf, N. K. K., Littke, R., and Lünsdorf, N. K. K.: Hydrocarbon generation and migration under a large overthrust: The carbonate platform under the Semail Ophiolite, Jebel Akhdar, Oman, Int. J. Coal Geol., 168, 1-17, https://doi.org/10.1016/j.coal.2016.02.007, 2016.

Grobe, A., Virgo, S., von Hagke, C., Urai, J. L. L., and Littke, R.: Multiphase Structural Evolution of a Continental Margin During Obduction Orogeny: Insights From the Jebel Akhdar Dome, Oman Mountains, Tectonics, 37, 888-913, https://doi.org/10.1002/2016TC004442, 2018.

Guenther, W. R., Reiners, P. W., Ketcham, R. A., Nasdala, L., and Giester, G.: Helium diffusion in natural zircon: Radiation damage, anisotropy, and the interpretation of zircon (U-Th)/He thermochronology, Am. J. Sci., 313, 145-198, https://doi.org/10.2475/03.2013.01, 2013.

Hacker, B. R. and Mosenfelder, J. L.: Metamorphism and deformation along the emplacement thrust of the Samail ophiolite, Oman, Earth Planet. Sc. Lett., 144, 435-451, https://doi.org/10.1016/S0012-821X(96)00186-0, 1996.

Hacker, B. R., Mosenfelder, J. L., and Gnos, E.: Rapid emplacement of the Oman ophiolite: Thermal and geochronologic constraints, Tectonics, 15, 1230-1247, 1996.

Hanna, S. S.: The Alpine deformation of the Central Oman Mountains, Geol. Soc. London, Spec. Publ., 49, 341-359, https://doi.org/10.1144/GSL.SP.1992.049.01.21, 1990.

Hansman, R. J., Ring, U., Thomson, S. N., and Den Brok, B.: Late Eocene uplift of the Al Hajar Mountains, Oman, supported by stratigraphy and low-temperature thermochronology, Tectonics, 36, 3081-3109, https://doi.org/10.1002/2017TC004672, 2017.

Hansman, R. J., Albert, R., Gerdes, A., and Ring, U.: Absolute ages of multiple generations of brittle structures by $\mathrm{U}-\mathrm{Pb}$ dating of calcite, Geology, 46, 207-210, https://doi.org/10.1130/G39822.1, 2018.

Hassanzadeh, J. and Wernicke, B. P.: The Neotethyan Sanandaj-Sirjan zone of Iran as an archetype for passive margin-arc transitions, Tectonics, 25, 586-621, https://doi.org/10.1002/2015TC003926, 2016.

Hilgers, C., Kirschner, D. L., Breton, J. P. P., and Urai, J. L.: Fracture sealing and fluid overpressures in limestones of the Jabal Akhdar dome, Oman mountains, Geofluids, 6, 168-184, https://doi.org/10.1111/j.1468-8123.2006.00141.x, 2006.

Hillier, S., Mátyás, J., Matter, A., and Vasseur, G.: Illite/smectite diagenesis and its variable correlation with vitrinite reflectance 
in the Pannonian Basin, Clays Clay Miner., 43, 174-183, https://doi.org/10.1346/CCMN.1995.0430204, 1995.

Holland, M., Saxena, N., and Urai, J. L.: Evolution of fractures in a highly dynamic thermal, hydraulic, and mechanical system (II) Remote sensing fracture analysis, Jabal Shams, Oman mountains, GeoArabia, 14, 163-194, 2009a.

Holland, M., Urai, J. L., Muchez, P., and Willemse, E. J. M.: Evolution of fractures in a highly dynamic thermal, hydraulic, and mechanical system - (I) Field observations in Mesozoic Carbonates, Jabal Shams, Oman Mountains, GeoArabia, 14, 57-110, $2009 \mathrm{~b}$.

Homewood, P., Razin, P., Grélaud, C., Droste, H., Vahrenkamp, V., Mettraux, M., and Mattner, J.: Outcrop sedimentology of the Natih Formation, northern Oman: A field guide to selected outcrops in the Adam Foothills and Al Jabal al Akhdar areas, GeoArabia, 13, 39-120, 2008.

Immenhauser, A. and Scott, R. W.: An estimate of Albian sea-level amplitudes and its implication for the duration of stratigraphic hiatuses, Sediment. Geol., 152, 19-28, https://doi.org/10.1016/S0037-0738(02)00260-9, 2002.

Immenhauser, A., Schlager, W., Burns, S. J., Scott, R. W., Geel, T., Lehmann, J., van der Gaast, S., and Bolder-Schrijver, L. J. A. J. A.: Late Aptian to late Albian sea-level fluctuations constrained by geochemical and biological evidence (Nahr Umr Formation, Oman), J. Sediment. Res., 69, 434-446, https://doi.org/10.2110/jsr.69.434, 1999.

Jacobs, J., Thomas, R. J., Ksienzyk, A. K., and Dunkl, I. I.: Tracking the Oman Ophiolite to the surface - New fission track and $(\mathrm{U}-\mathrm{Th}) / \mathrm{He}$ data from the Aswad and Khor Fakkan Blocks, United Arab Emirates, Tectonophysics, 644, 68-80, https://doi.org/10.1016/j.tecto.2014.12.018, 2015.

Jirman, P., Geršlová, E., Kalvoda, J., and Melichar, R.: 2d basin modelling in the eastern variscan fold belt (Czech Republic): influence of thrusting on patterns of thermal maturation, J. Pet. Geol., 41, 175-188, https://doi.org/10.1111/jpg.12699, 2018.

Ketcham, R. A.: Forward and Inverse Modeling of LowTemperature Thermochronometry Data, Rev. Mineral. Geochemistry, 58, 275-314, https://doi.org/10.2138/rmg.2005.58.11, 2005.

Ketcham, R. A., Mora, A., and Parra, M.: Deciphering exhumation and burial history with multi-sample down-well thermochronometric inverse modelling, Basin Res., 30, 48-64, https://doi.org/10.1111/bre.12207, 2018.

Koehrer, B., Zeller, M., Aigner, T., Poeppelreiter, M., Milroy, P., Forke, H., and Al-Kindi, S.: Facies and stratigraphic framework of a Khuff outcrop equivalent: Saiq and Mahil formations, Al Jabal al-Akhdar, Sultanate of Oman, GeoArabia, 15, 91-156, 2010.

Koehrer, B., Aigner, T., and Poppelreiter, M.: Field-scale geometries of Upper Khuff reservoir geobodies in an outcrop analogue (Oman Mountains, Sultanate of Oman), Pet. Geosci., 17, 3-16, https://doi.org/10.1144/1354-079310-009, 2011.

Kouketsu, Y., Mizukami, T., Mori, H., Endo, S., Aoya, M., Hara, H., Nakamura, D., and Wallis, S.: A new approach to develop the Raman carbonaceous material geothermometer for low-grade metamorphism using peak width, Isl. Arc, 23, 33-50, https://doi.org/10.1111/iar.12057, 2014.

Le Metour, J., Rabu, D., Tegyey, M., Bechennec, F., Beurrier, M., and Villey, M.: Subduction and obduction: two stages in the EoAlpine tectonometamorphic evolution of the Oman
Mountains, Geol. Soc. London, Spec. Publ., 49, 327-339, https://doi.org/10.1144/GSL.SP.1992.049.01.20, 1990.

Levina, M., Horton, B. K., Fuentes, F., and Stockli, D. F.: Cenozoic sedimentation and exhumation of the foreland basin system preserved in the Precordillera thrust belt $\left(31-32^{\circ} \mathrm{S}\right)$, southern central Andes, Argentina, Tectonics, 33, 1659-1680, https://doi.org/10.1002/2013TC003424, 2014.

Lippard, S. J., Smewing, J. D., Rothery, D. A., and Browning, P.: The geology of the Dibba zone, northern Oman mountains - a preliminary study, J. Geol. Soc. London, 139, 59-66, https://doi.org/10.1144/gsjgs.139.1.0059, 1982.

Loosveld, R. J. H., Bell, A., and Terken, J. J. M.: The Tectonic Evolution of Interior Oman, GeoArabia, 1, 28-51, 1996.

Lünsdorf, N. K.: Raman spectroscopy of dispersed vitrinite - methodical aspects and correlation with reflectance, Int. J. Coal Geol., 153, 75-86, https://doi.org/10.1016/j.coal.2015.11.010, 2016.

Lünsdorf, N. K., Dunkl, I., Schmidt, B. C., Rantitsch, G., and von Eynatten, H.: The thermal history of the Steinach Nappe (eastern Alps) during extension along the Brenner Normal Fault system indicated by organic maturation and zircon (U-Th)/ He thermochronology, Aust. J. Earth Sci., 105, 17-25, 2012.

Lünsdorf, N. K., Dunk1, I., Schmidt, B. C., Rantitsch, G., and von Eynatten, H.: Towards a Higher Comparability of Geothermometric Data Obtained by Raman Spectroscopy of Carbonaceous Material. Part 2: A Revised Geothermometer, Geostand. Geoanalytical Res., 41, 593-612, https://doi.org/10.1111/ggr.12178, 2017.

Mair, D., Lechmann, A., Herwegh, M., Nibourel, L., and Schlunegger, F.: Linking Alpine deformation in the Aar Massif basement and its cover units - the case of the Jungfrau-Eiger mountains (Central Alps, Switzerland), Solid Earth, 9, 1099-1122, https://doi.org/10.5194/se-9-1099-2018, 2018.

Mann, A., Hanna, S. S., and Nolan, S. C.: The post-Campanian tectonic evolution of the Central Oman Mountains: Tertiary extension of the Eastern Arabian Margin, Geol. Tectonics Oman Reg., 49, 549-563, https://doi.org/10.1144/gsl.sp.1992.049.01.33, 1990.

Mashhadi, Z. S., Rabbani, A. R., and Kamali, M. R.: Geochemical characteristics and hydrocarbon generation modeling of the Kazhdumi (Early Cretaceous), Gurpi (Late Cretaceous) and Pabdeh (Paleogene) formations, Iranian sector of the Persian Gulf, Mar. Pet. Geol., 66, 978-997, https://doi.org/10.1016/J.MARPETGEO.2015.08.008, 2015.

Mattern, F. and Scharf, A.: Postobductional extension along and within the Frontal Range of the Eastern Oman Mountains, J. Asian Earth Sci., 154, 369-385, https://doi.org/10.1016/j.jseaes.2017.12.031, 2018.

Mount, V. S., Crawford, R. I. S., Bergmann, S., and Bergman, S. C.: Regional Structural Style of the Central and Southern Oman Mountains: Jebel Akhdar, Saih Hatat, and the Northern Ghaba Basin, GeoArabia, 3, 17, 1998.

Mouthereau, F.: Timing of uplift in the Zagros belt/Iranian plateau and accommodation of late Cenozoic Arabia - Eurasia convergence, Geol. Mag., 148, 726-738, https://doi.org/10.1017/S0016756811000306, 2011.

Mozafari, M., Swennen, R., Balsamo, F., Clemenzi, L., Storti, F., El Desouky, H., Vanhaecke, F., Tueckmantel, C., Solum, J., and Taberner, C.: Paleofluid Evolution In Fault-Damage Zones: Evi- 
dence From Fault-Fold Interaction Events In the Jabal Qusaybah Anticline (Adam Foothills, North Oman), J. Sediment. Res., 85, 1525-1551, https://doi.org/10.2110/jsr.2015.95, 2015.

Muchez, P., Marshall, J. D., Touret, J. L. R., and Viaene, W. A.: Origin and migration of palaeofluids in the Upper Visean of the Campine Basin, northern Belgium, Sedimentology, 41, 133-145, https://doi.org/10.1111/j.1365-3091.1994.tb01395.x, 1994.

Neumaier, M.: Structural Restoration and Basin and Petroleum Systems Modeling: Case Studies from the Monagas Fold and Thrust Belt, Venezuela and the Moroccan Atlantic Margin, Dissertation, RWTH Aachen University, 2015.

Nibourel, L., Berger, A., Egli, D., Luensdorf, N. K., and Herwegh, M.: Large vertical displacements of a crystalline massif recorded by Raman thermometry, Geology, 46, 879-882, https://doi.org/10.1130/G45121.1, 2018.

Nicolas, A. and Boudier, F. F.: Structural contribution from the Oman ophiolite to processes of crustal accretion at the East Pacific Rise, Terra Nov., 27, 77-96, https://doi.org/10.1111/ter.12137, 2015.

Nolan, S. C., Skelton, P. W., Clissold, B. P., and Smewing, J. D.: Maastrichtian to early Tertiary stratigraphy and palaeogeography of the Central and Northern Oman Mountains, Geol. Soc. London, Spec. Publ., 49, 495-519, https://doi.org/10.1144/gsl.sp.1992.049.01.31, 1990.

Nöth, S., Karg, H., and Littke, R.: Reconstruction of Late Paleozoic heat flows and burial histories at the RhenohercynianSubvariscan boundary, Germany, Int. J. Earth Sci., 90, 234-256, https://doi.org/10.1007/s005310000114, 2001.

Oliver, J.: Fluids expelled tectonically from orogenic belts: Their role in hydrocarbon migration and other geologic phenomena, Geology, 14, 99-102, 1986.

Oxburgh, E. R. and Turcotte, D. L.: Thermal gradients and regional metamorphism in overthrust terrains with special reference to the Eastern Alps, Schweizerische Mineral. und Petrogr. Mitteilungen, 54, 642-662, 1974.

Philip, J., Borgomano, J., and Al-Maskiry, S.: Cenomanian-Early Turonian carbonate platform of Northern Oman: stratigraphy and palaeo-environments, Palaeogeogr. Palaeocl., 119, 77-92, 1995.

Pöppelreiter, M. C., Schneider, C. J., Obermaier, M., Forke, H. C., Koehrer, B., and Aigner, T.: Seal turns into reservoir: Sudair equivalents in outcrops, A1 Jabal al-Akhdar, Sultanate of Oman, GeoArabia, 16, 69-108, 2011.

Poupeau, G., Saddiqi, O., Michard, A., Goffé, B., and Oberhänsli, R.: Late thermal evolution of the Oman Mountains subophiolitic windows: Apatite fission-track thermochronology, Geology, 26, 1139-1142, 1998.

Pratt, R., Smewing, D., Swansea, S. A., Pratt, B. R., and Smewing, J. D.: Jurassic and Early Cretaceous platform margin configuration and evolution, central Oman Mountains, Geol. Soc. London, Spec. Publ., 49, 69-88, https://doi.org/10.1144/GSL.SP.1992.049.01.06, 1990.

Rabu, D., Le Metour, J., Bechennec, F., Beurrier, M., Villey, M., and Bourdillon-Jeudy de Grissac, C.: Sedimentary aspects of the Eo-Alpine cycle on the northeast edge of the Arabian Platform (Oman Mountains), Geol. Soc. London, Spec. Publ., 49, 49-68, https://doi.org/10.1144/GSL.SP.1992.049.01.05, 1990.

Rantitsch, G. and Rainer, T.: Thermal modeling of Carboniferous to Triassic sediments of the Karawanken Range (Southern Alps) as a tool for paleogeographic reconstructions in the
Alpine-Dinaridic-Pannonian realm, Int. J. Earth Sci., 92, 195209, https://doi.org/10.1007/s00531-003-0312-4, 2003.

Reiners, P. W.: Zircon (U-Th)/He Thermochronometry, Rev. Mineral. Geochem., 58, 151-179, https://doi.org/10.2138/rmg.2005.58.6, 2005.

Reutter, K.-J., Teichmüller, M., and Teichmüller, R.: The Coalification Pattern in the Northern Apennines and its Palaeogeothermic and Tectonic Significance, Geol. Rundschau, 72, 861-894, 1988.

Rioux, M., Bowring, S., Kelemen, P., Gordon, S., Miller, R., and Dudás, F.: Tectonic development of the Samail ophiolite: Highprecision $\mathrm{U}-\mathrm{Pb}$ zircon geochronology and $\mathrm{Sm}-\mathrm{Nd}$ isotopic constraints on crustal growth and emplacement, J. Geophys. Res.Sol. Ea., 118, 2085-2101, https://doi.org/10.1002/jgrb.50139, 2013.

Rioux, M., Garber, J., Bauer, A., Bowring, S., Searle, M., Kelemen, P., and Hacker, B.: Synchronous formation of the metamorphic sole and igneous crust of the Semail ophiolite: New constraints on the tectonic evolution during ophiolite formation from highprecision U-Pb zircon geochronology, Earth Planet. Sc. Lett., 451, 185-195, https://doi.org/10.1016/j.epsl.2016.06.051, 2016.

Robertson, A.: The transition from a passive margin to an Upper Cretaceous foreland basin related to ophiolite emplacement in the Oman Mountains, Geol. Soc. Am. Bull., 99, 633-653, https://doi.org/10.1130/00167606(1987)99<633:TTFAPM>2.0.CO;2, 1987.

Rolandone, F., Lucazeau, F., Leroy, S., Mareschal, J.-C., Jorand, R., Goutorbe, B., and Bouquerel, H.: New heat flow measurements in Oman and the thermal state of the Arabian Shield and Platform, Tectonophysics, 589, 77-89, https://doi.org/10.1016/j.tecto.2012.12.034, 2013.

Roure, F., Andriessen, P., Callot, J. P., Faure, J. L., Ferket, H., Gonzales, E., Guilhaumou, N., Lacombe, O., Malandain, J., Sassi, W., Schneider, F., Swennen, R., Vilasi, N., Box, P. O., Gonzales, E., Guilhaumou, N., Lacombe, O., Malandain, J., Sassi, W., Schneider, F., Swennen, R., and Vilasi, N.: The use of palaeothermo-barometers and coupled thermal, fluid flow and porefluid pressure modelling for hydrocarbon and reservoir prediction in fold and thrust belts, Geol. Soc. London, Spec. Publ., 348, 87-114, https://doi.org/10.1144/SP348.6, 2010.

Saddiqi, O., Michard, A. N., Goffe, B. R., Poupeau, G. É., and Oberhänsli, R. O.: Fission-track thermochronology of the Oman Mountains continental windows, and current problems of tectonic interpretation, Bull. la Soc. Geol. Fr., 177, 127-143, https://doi.org/10.2113/gssgfbull.177.3.127, 2006.

Schito, A., Corrado, S., Trolese, M., Aldega, L., Caricchi, C., Cirilli, S., Grigo, D., Guedes, A., Romano, C., Spina, A., and Valentim, B.: Assessment of thermal evolution of Paleozoic successions of the Holy Cross Mountains (Poland), Mar. Pet. Geol., 80, 112-132, https://doi.org/10.1016/J.MARPETGEO.2016.11.016, 2017.

Schito, A., Andreucci, B., Aldega, L., Corrado, S., Di Paolo, L., Zattin, M., Szaniawski, R., Jankowski, L., and Mazzoli, S.: Burial and exhumation of the western border of the Ukrainian Shield (Podolia): a multi-disciplinary approach, Basin Res., 30, 532549, https://doi.org/10.1111/bre.12235, 2018.

Scott, R. W.: Chronostratigraphy of the Cretaceous carbonate shelf, southeastern Arabia, Geol. Soc. London, Spec. Publ., 49, 89108, https://doi.org/10.1144/GSL.SP.1992.049.01.07, 1990. 
Searle, M. P.: Sequence of thrusting and origin of culminations in the northern and central Oman Mountains, J. Struct. Geol., 7, 129-143, https://doi.org/10.1016/0191-8141(85)90127-0, 1985.

Searle, M. P.: Structural geometry, style and timing of deformation in the Hawasina Window, Al Jabal al Akhdar and Saih Hatat culminations, Oman Mountains, GeoArabia, 12, 99-130, 2007.

Searle, M. P. and Cox, J. O. N.: Subduction zone metamorphism during formation and emplacement of the Semail ophiolite in the Oman Mountains, Geol. Mag., 139, 241-255, https://doi.org/10.1017/S0016756802006532, 2002

Searle, M. P., Warren, C. J., Waters, D. J., and Parrish, R. R.: Subduction zone polarity in the Oman Mountains: implications for ophiolite emplacement, Geol. Soc. London, Spec. Publ., 218, 467-480, https://doi.org/10.1144/GSL.SP.2003.218.01.24, 2003.

Searle, M. P., Warren, C. J. J., Waters, D. J., and Parrish, R. R.: Structural evolution, metamorphism and restoration of the Arabian continental margin, Saih Hatat region, Oman Mountains, J. Struct. Geol., 26, 451-473, https://doi.org/10.1016/j.jsg.2003.08.005, 2004.

Secor Jr., D. T.: Role of fluid pressure in jointing, Am. J. Sci., 263, 633-646, 1965.

Stenhouse, P.: Reactive Transport and Fluid Pathways in FractureControlled Flow Systems, Doctoral Dissertation, Australian National University, 2014.

Sweeney, J. J. and Burnham, A. K.: Evaluation of a Simple Model of Vitrinite Reflectance Based on Chemical Kinetics, Am. Assoc. Pet. Geol. Bull., 74, 1559-1570, 1990.

Teichmüller, R. and Teichmüller, M.: Relations between coalification and palaeogeothermics in Variscan and Alpidic foredeeps of western Europe, Lect. Notes Earth Sci., 5, 53-78, 1986.

Terken, J. M. J.: The Natih petroleum system of north Oman, GeoArabia, 4, 157-180, 1999.

Terken, J. M. J., Frewin, N. L., Indrelid, S. L., and Indrelin, S. L.: Petroleum systems of Oman: Charge timing and risks, Am. Assoc. Pet. Geol. Bull., 85, 1817-1845, 2001.

Vahrenkamp, V. C.: Chemostratigraphy of the Lower Cretaceous Shu' aiba Formation: A delta $-{ }^{13} \mathrm{C}$ reference profile for the Aptian Stage from the southern Neo-Tethys Ocean, GeoArabia, 1, 107137,2010

Van Buchem, F. S. P., Razin, P., Homewood, P. W., Philip, J. M., Eberli, G. P., Platel, J. P., Roger, J., Eschard, R., Desaubliaux, G. M. J., Boisseau, T., Leduc, J. P., Labourdette, R., and Cantaloube, S.: High resolution sequence stratigraphy of the Natih Formation (Cenomanian/Turonian) in northern Oman: distribution of source rocks and reservoir facies, GeoArabia, 1, 65-91, 1996.

Van Buchem, F. S. P., Razin, P., Homewood, P. W., Oterdoom, W. H., and Philip, J.: Stratigraphic organization of carbonate ramps and organic- rich intrashelf basins: Natih Formation (middle Cretaceous) of northern Oman, Am. Assoc. Pet. Geol. Bull., 86, 21-53, https://doi.org/10.1306/61EEDA30173E-11D7-8645000102C1865D, 2002.
Van Den Kerkhof, A. M. and Hein, U. F.: Fluid inclusion petrography, Lithos, 55, 27-47, 2001.

Velde, B. and Lanson, B.: Comparison of I/S transformation and maturity of organic matter at elevated temperatures, Clays Clay Miner., 41, 178-183, 1993.

Vermeesch, P.: How many grains are needed for a provenance study?, Earth Planet. Sc. Lett., 224, 441-451, https://doi.org/10.1016/J.EPSL.2004.05.037, 2004.

Virgo, S.: Aspects of crack-seal vein system evolution, Doctoral Dissertation, available at: http://nbn-resolving.de/urn/resolver. pl?urn=urn:nbn:de:hbz:82-opus-33858 (last access: January 2019), RWTH Aachen University, 2015.

Virgo, S. and Arndt, M.: Evolution of a crack-seal calcite vein network in limestone: a high resolution structural, microstructural and geochemical study from the Jebel Akhdar high pressure cell, Oman Mountains, Diploma Thesis, RWTH Aachen, available at: https://d-nb.info/1008285536/34 (last access: January 2019), 2010.

Virgo, S., Abe, S., and Urai, J. L.: Extension fracture propagation in rocks with veins: Insight into the crack-seal process using Discrete Element Method modeling, J. Geophys. Res.-Sol. Ea., 118, 5236-5251, https://doi.org/10.1002/2013JB010540, 2013a.

Virgo, S., Arndt, M., Sobisch, Z. Z., and Urai, J. L.: Development of fault and vein networks in a carbonate sequence near Hayl al-Shaz, Oman Mountains, GeoArabia, 18, 99-136, 2013b.

Visser, W.: Burial and thermal history of Proterozoic source rocks in Oman, Precambrian Res., 54, 15-36, https://doi.org/10.1016/0301-9268(91)90066-J, 1991.

von Hagke, C., Cederbom, C. E., Oncken, O., Stöckli, D. F., Rahn, M. K., and Schlunegger, F.: Linking the northern Alps with their foreland: The latest exhumation history resolved by low-temperature thermochronology, Tectonics, 31, https://doi.org/10.1029/2011TC003078, 2012.

Warburton, J., Burnhill, T. J., Graham, R. H., and Isaac, K. P.: The evolution of the Oman Mountains Foreland Basin, Geol. Soc. London, Spec. Publ., 49, 419-427, https://doi.org/10.1144/GSL.SP.1992.049.01.26, 1990.

Warren, C. J., Parrish, R. R., Searle, M. P., and Waters, D. J.: Dating the subduction of the Arabian continental margin beneath the Semail ophiolite, Oman, Geology, 31, 889, https://doi.org/10.1130/G19666.1, 2003.

Warren, C. J., Parrish, R. R., Waters, D. J., and Searle, M. P.: Dating the geologic history of Oman's Semail ophiolite: insights from U-Pb geochronology, Contrib. to Mineral. Petrol., 150, 403-422, https://doi.org/10.1007/s00410-005-0028-5, 2005.

Wygrala, B. P.: Integrated study on an oil field in the southern po basin, northern italy, Berichte der Kernforschungsanlage Jülich, 2313, 217 pp., 1989. 